\title{
Characterization of carbon and microbial biomass pools in shallow water coastal sediments of the southern Baltic Sea (Nordrügensche Bodden)
}

\author{
Marion Köster*, Lutz-Arend Meyer-Reil \\ Institut für Ökologie der Ernst-Moritz-Arndt-Universität Greifswald, 18565 Kloster/Hiddensee, Germany
}

\begin{abstract}
Relations between sediment properties and pools of organic carbon and microbial biomass were investigated in sediments of shallow water coastal inlets of the southern Baltic Sea (Rassower Strom, Nordrügensche Bodden). According to their mud content (percentage of the fraction $<63 \mu \mathrm{m}$ to total sediment dry weight), sediments were grouped into sand, slightly muddy sand, and muddy sand. Phospholipids and ATP were analysed to estimate total and 'active' microbial biomass. From measurements of chlorophyll a ( $\mathrm{chl} a$ ) and total bacterial numbers, photoautotrophic microbial and bacterial biomasses were estimated. Carbon pools were determined by total organic carbon (TOC), dissolved organic and inorganic carbon (DOC, DIC), and available dissolved organic carbon (ADOC). The latter was measured by means of a biosensor consisting of an oxygen microelectrode with bacteria attached to the tip. Nitrogen and phosphorus were also analysed. Size and composition of carbon pools and microbial biomass revealed pronounced differences related to the mud content of the sediments. Sandy sediments were characterized by a high contribution of DOC and ADOC to TOC. Microbial biomass could be equally estimated by phospholipid-, ATP-, and chl-a-based carbon. Bacterial carbon constituted $5 \%$ of the total microbial biomass carbon. With increasing mud content from sandy and slightly muddy sand towards muddy sand sediments, TOC and DOC increased, whereas ADOC decreased. In the same way, total microbial (phospholipid based) and bacterial biomass increased; whereas the contribution of photoautotrophic (chl a based) and active (ATP based) biomass to total biomass declined to 31 and $18 \%$, respectively. As demonstrated by increasing ratios of carbon to nitrogen, nitrogen to phosphorus, and decreasing ratios of chl a to phaeopigments, the organic matter undergoes increasing aging from sandy to muddy sand sediments. Pronounced relationships between phospholipid and bacterial based biomass on the one hand and between ATP and $\mathrm{chl} a$ on the other suggested similar structural and physiological features of corresponding biomass indicators. Total phospholipid based microbial biomass and bacterial biomass were closely related to mud content as well as to organic matter (carbon, nitrogen), whereas photoautotrophic and 'active' microbial biomass measured as chl $a$ and ATP seemed to be inversely related to mud content. From the direct relation between photoautotrophic biomass and ADOC, it is suggested that easily decomposable carbon for microbial utilization was supported by exudation during photosynthesis.
\end{abstract}

KEY WORDS: Sediment properties - Total organic carbon - Dissolved organic carbon · Available dissolved organic carbon $\cdot$ Microbial biosensor $\cdot$ Microbial biomass $\cdot$ Baltic Sea

\section{INTRODUCTION}

Sediments are complex systems affected by geological, hydrodynamical, physicochemical, chemical, and biological parameters, the interaction of which char-

*E-mail: koesterm@mail.uni-greifswald.de acterizes the sedimentary environment. On a shortterm scale environmental parameters such as water movements, light, temperature, and inorganic and organic nutrients determine the structure and activity patterns of microbial benthic communities, which in turn influence the diagenetic milieu through their metabolism (e.g. Deming \& Baross 1993). The pool of organic matter in sediments may be arbitrarily sepa- 
rated into different fractions. The overwhelming portion exists in the form of particulate carbon (POC), most of which is refractory and undergoes only slow degradation by microorganisms. Dissolved organic carbon (DOC) and biomass carbon (BMC) make up only a few percent of the total organic carbon content (TOC) of sediments. The different carbon fractions are closely linked together. Through the death and decay of organisms, POC is liberated. POC may be formed de novo from DOC as well (e.g. Mari 1999). DOC is mainly supplied through the lysis of organisms (Bratbak et al. 1998), by exudation (e.g. Ziegler \& Benner 1999) and by excretion processes as well as by the microbially mediated hydrolysis of POC. Through the incorporation into microorganisms, DOC is converted into BMC thus available for higher trophical levels. On the other hand, DOC may be adsorbed to particles, thus protected from microbial degradation, and temporarily stored (e.g. Keil et al. 1994, Borch \& Kirchman 1999).

The DOC pool is composed of various low and high molecular weight dissolved organic compounds of different availability for microorganisms (e.g. SañudoWilhelmy \& Taylor 1999). Of special interest is the available dissolved organic carbon (ADOC) that microorganisms rely on to meet their carbon and energy demand. This fraction tends to have short turnover times as it is rapidly metabolized by heterotrophic microorganisms. The continuous supply of this fraction through various processes is one of the prerequisites for microbial metabolism (Meyer-Reil 1994). Despite its importance for microbial metabolism in sediments, little is known about the concentration and turnover of ADOC, due to the analytical difficulties of separating ADOC from DOC. Since the chemical analysis of assimilable organic carbon is limited by the broad spectrum of chemical compounds, bioassays have been described to characterize the pool of ADOC. Recently, a biosensor has been developed for the measurement of ADOC in aerobic sediments (Neudörfer \& Meyer-Reil 1997, and literature cited therein).

As a measure of the microbial biomass pool in sediments, cell constituents such as phospholipids, ATP, chlorophyll $a(\mathrm{chl} a$ ) and, in the case of bacteria, numbers have been determined (see Parkes 1987, Fry 1988, White et al. 1997). For the extrapolation of microbial biomass, conversion factors are required to account for the relationship between concentration of the corresponding biomarker and organic carbon (e.g. Karl 1980, Meyer-Reil 1983, Bott \& Kaplan 1985, Fry 1988, Findlay et al. 1989, Herbert 1990, Cammen 1991, de Jonge \& Colijn 1994). The conversion factors reported in the literature, however, suffer from the fact that they greatly vary between different taxonomical groups and physiological status of the cells.
Furthermore, biomarkers such as phospholipids and ATP are common to procaryotic and eucaryotic organisms. Only in the case of chl $a$ and bacterial numbers may photoautotrophic and heterotrophic microorganisms be separated.

From the early literature general relationships between sediment properties (e.g. grain size, available surface area, porosity, organic matter content) and benthic microbiota are well known. Fine-grained sediments carry a high organic matter content and support a higher microbial biomass as compared to coarse sediments (e.g. Hargrave 1972, Dale 1974, de Flaun \& Mayer 1983, Meyer-Reil 1986, Mayer 1994). This means that grain size is inversely correlated to available surface area, porosity, organic matter and microbial biomass. For a direct comparison of data from different sediments, however, differences in the bulk density of the sediments have to be considered (Bird \& Duarte 1989, Delafontaine et al. 1996). Apart from the general relationships between grain size and microbial biomass, much less is known about the influence of sediment properties on microbial activities. Bott \& Kaplan (1985) assumed that the influence of sediment properties is more strongly reflected in the biomass than in the activity of the microbial communities. Microbial activity parameters seem to be primarily controlled by the availability and nutritional quality of degradable organic matter (e.g. Fabiano \& Danovaro 1998). In turn, microorganisms greatly influence the sediment environment through their metabolism (e.g. secretion of extracellular polymeric substances, modification and decomposition of inorganic and organic substrates).

The aim of the present study was to characterize the carbon and biomass pools along a gradient of sediments of increasing mud content. It was of special interest to relate changes in quantity and quality of organic matter to the composition of microbial biomass. For this purpose, the significance of different fractions of the pools of organic carbon and microbial biomass in relation to sediment properties was investigated in sediments of the Rassower Strom, a shallow coastal inlet of the southern Baltic Sea (Germany). Sediments were classified according to their mud contents (expressed as the contribution of the fraction $<63 \mu \mathrm{m}$ to total sediment dry weight), water contents and concentrations of carbon, nitrogen and phosphorus. The benthic microbial community was characterized by various biomass parameters (phospholipids, ATP, chl $a$, bacterial counts) and related to the size and composition of the different carbon pools (TOC, DOC). For the first time, to our knowledge, the pool size of ADOC, determined with a biosensor, could be included in the measurements and related to carbon pools and microbial biomass. 


\section{MATERIALS AND METHODS}

Sampling. Eight stations differing in sediment properties were sampled from the Rassower Strom between June 22 and July 3, 1998. This study site is located in the outer part of the Nordrügensche Bodden, which are shallow water coastal inlets of the southern Baltic Sea (Germany). Four stations increasing in water depths from 0.5 to $4.5 \mathrm{~m}$ were located along a westeast transect; the other stations (water depths between 2.1 and $4.3 \mathrm{~m}$ ) were located close to the shipping channel (Fig. 1). Salinity and temperature in the water above the sediments were measured using probes (microprocessor conductivity meter LF 196 with integrated temperature sensor, Wissenschaftliche Technische Werkstätten GmbH). During the sampling period, the water column was well mixed. Salinity ranged between 8.1 and 8.3 PSU, temperature between 17.4 and $19.6^{\circ} \mathrm{C}$.

Sediment cores were collected by divers in plexiglass tubes (length $30 \mathrm{~cm}$, inner diameter $10 \mathrm{~cm}$ ) at sites located along the transect. At the other locations, sediment samples were collected with a multiple corer (Barnett et al. 1984) modified for application to shallow waters. Within $2 \mathrm{~h}$ after sampling, the sediment cores were processed. For each station, 4 sediment cores with comparable properties (sediment texture, vegetation, faunal colonization) were chosen and sectioned into distinct horizons $(0-1,1-2,2-3,4-5,6-7$, and 9-10 cm). The material from corresponding horizons

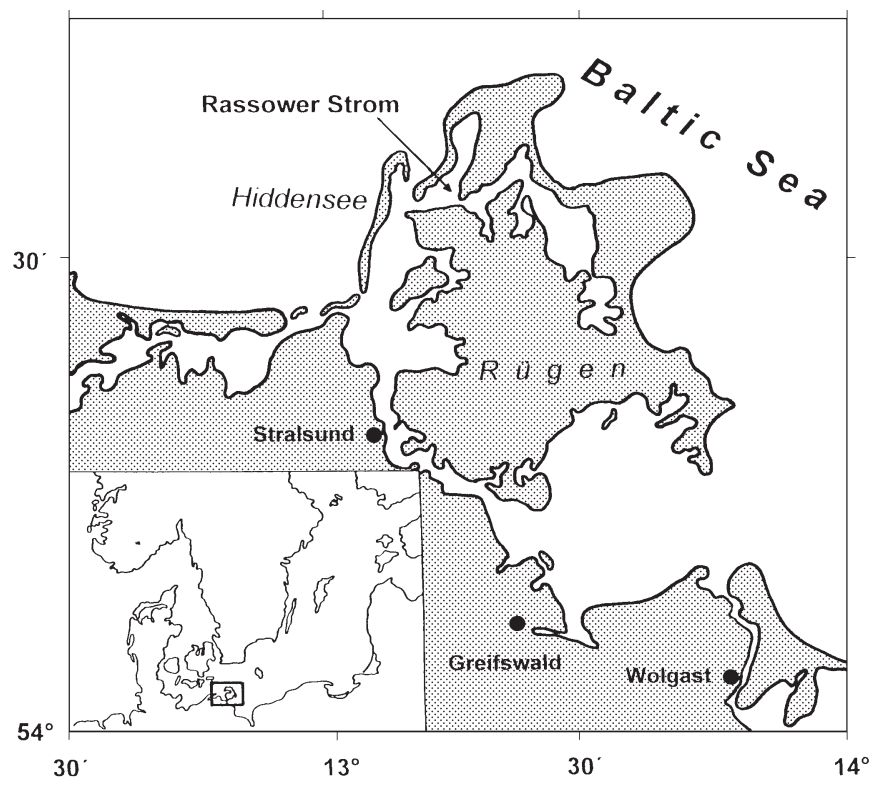

Fig. 1. The coastline of Mecklenburg-Vorpommern, Germany. The arrow indicates the investigation area in the Rassower Strom was combined and thoroughly mixed for analyses of various geochemical and microbiological parameters.

Characterization of sediments. Water content was determined after drying the sediments at $60^{\circ} \mathrm{C}$ for $48 \mathrm{~h}$. For sediment characterization, the contribution of the fraction $<63 \mu \mathrm{m}$ to the total sediment dry weight was analyzed in sediments treated with $\mathrm{H}_{2} \mathrm{O}_{2}$ (Figge et al. 1980). Organic carbon and nitrogen were determined in dried sediments exposed to concentrated $\mathrm{HCl}$ vapour for $48 \mathrm{~h}$ and subsequently treated with 1 or 2 drops of concentrated $\mathrm{HCl}$ to remove inorganic carbon. Sediments were combusted in a Heraeus vario-el $\mathrm{CHN}$-analyser at $950^{\circ} \mathrm{C}$ (Köster et al. 1997). Total and organic phosphorus in sediments were determined using the ignition method of Andersen (1976) modified as follows: 300 to $400 \mathrm{mg}$ of dried sediment (8 replicates) were split into 2 aliquots. One was ashed for $2 \mathrm{~h}$ at $550^{\circ} \mathrm{C}$ and treated with $25 \mathrm{ml}$ of $1 \mathrm{~N} \mathrm{HCl}$ for $5 \mathrm{~min}$ at $100^{\circ} \mathrm{C}$ to liberate total (inorganic and organic) phosphorus, while the other was treated with $\mathrm{HCl}$ only to liberate the inorganic phosphorus. The phosphorus released in both $\mathrm{HCl}$ extracts was measured as orthophosphate using standard spectrophotometric techniques (e.g. Grasshoff et al. 1999). Organic phosphorus was calculated as difference between total and inorganic phosphorus. Molar ratios between carbon, nitrogen and phosphorus were determined. All fractions of the sedimentary organic matter were quantified in terms of concentration (mg per volume) to account for differences in dry bulk densities of the sediments.

Dissolved inorganic and organic carbon. Dissolved inorganic carbon (DIC) and DOC concentrations were measured by high-temperature catalytic oxidation at $680^{\circ} \mathrm{C}$ in a Shimadzu TOC-5050 analyzer. Combustion gases (carbon dioxide) were transferred by synthetic air to an infrared analyser (details of the method are given by Cauwet 1999). Water overlying the sediments and pore water gained by centrifugation $\left(0^{\circ} \mathrm{C}, 4.000\right.$ rpm) were filtered through precombusted $\left(450^{\circ} \mathrm{C}\right)$ Whatman GF/F filters and subsequently through Sartorius $0.2 \mu \mathrm{m}$ pore-size cellulose nitrate filters to remove particulate material. Samples were stored in sealed glass ampoules at $-20^{\circ} \mathrm{C}$ until processing (Tupas et al. 1994). Calibration curves in the range

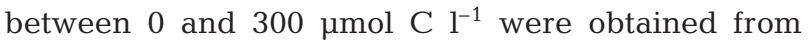
freshly prepared standard solutions of potassium hydrogen phthalate and sodium hydrogen carbonate. Standard deviations of total carbon (TC) and DIC measurements of standard solutions (injection volume: 30 to $50 \mu \mathrm{l}, 3$ to 5 replicates) were usually below $2 \%$. DOC concentrations of the samples were calculated from the difference between TC and DIC.

To study the possible influence of freezing on DOC concentration, $0.2 \mu \mathrm{m}$ pore size filtered standard solu- 
tions of potassium hydrogen phthalate $\left(10 \mathrm{mg} \mathrm{l}^{-1}\right)$ and pore water samples with DOC concentrations between 8 and $21 \mathrm{mg} \mathrm{l}^{-1}$ gained from surface $(0$ to $2 \mathrm{~cm}$ ) and subsurface (8 to $10 \mathrm{~cm}$ ) sediments of the Rassower Strom (November 1, 1998) were frozen in glass ampoules at $-20^{\circ} \mathrm{C}$ and stored for different periods up to $3 \mathrm{mo}$. Two to three replicates from each horizon were analysed for each storage interval. During storage, mean average values of DOC measured in surface and subsurface pore water samples differed by $4 \%$ and $8 \%$, respectively, from values measured immediately after collection. To estimate possible effects of oxygen on DOC concentration of anoxic pore waters, sediment cores of the Rassower Strom (November 30, 1998) were sliced in a glove box under a helium atmosphere. Anoxic sediments of the 9 to $10 \mathrm{~cm}$ horizon were homogenized and split into 2 parts. One set of mixed sediment was exposed to atmospheric oxygen; the other set was kept anaerobically under a helium atmosphere. With the exception of the exposure to oxygen, the 2 sets of sediments were treated in the same manner with regard to gaining pore water and subsequent filtration. Subsamples of $1 \mathrm{ml}$ were filled into helium flushed vials, which were opened immediately before analysis. Changes in DOC concentrations observed in anoxic pore waters after exposure to atmospheric oxygen were generally less than $10 \%$ compared to anaerobically processed pore waters.

Available dissolved organic carbon. ADOC was measured with a microbial biosensor consisting of a Clark type oxygen microelectrode with immobilized microbial cells at the tip (Neudörfer \& Meyer-Reil 1997). The aerobic heterotrophic bacteria strain GB1 originally isolated from the Bodden waters was grown in ZoBell medium (salinity: 9 PSU) up to the early stationary phase, washed with carbon free mineral salt medium $\left(5 \mathrm{~g} \mathrm{NaCl}_{1} 1 \mathrm{~g} \mathrm{KCl} 1 \mathrm{~g} \mathrm{NH}_{4} \mathrm{Cl}, 0.5 \mathrm{~g}\right.$ $\mathrm{K}_{2} \mathrm{HPO}_{4} \cdot 3 \mathrm{H}_{2} \mathrm{O}, 0.2 \mathrm{~g} \mathrm{MgSO}_{4} \cdot 7 \mathrm{H}_{2} \mathrm{O}$ and $0.1 \mathrm{~g} \mathrm{CaCl}_{2}$. $2 \mathrm{H}_{2} \mathrm{O}$ per $1000 \mathrm{ml}$ of bidistilled water) and harvested by centrifugation $\left(4^{\circ} \mathrm{C}, 2585 \times g\right)$. Cells were embedded in a mixture of 5\% polyvinyl-alcohol and $11 \%$ polyurethane in the ratio of 45:11:44 wt\% and filled into a silane covered glass tip. The cell matrix was dried for $24 \mathrm{~h}$ at room temperature. Prior to use, the dried matrix with a thickness of $200 \mu \mathrm{m}$ was soaked in carbon free mineral salt medium for $24 \mathrm{~h}$. An oxygen microelectrode was connected to a current/voltage transducer and stepwise inserted into the matrix with the aid of a micromanipulator. As soon as the microelectrode passed the surface of the cell matrix, oxygen concentrations continuously decreased to a minimum in the inner part of the matrix. Moving the electrode further downwards, oxygen concentrations increased again near the interface of the matrix, where the sensor was positioned. After positioning the micro- electrode, the glass tip with the immobilized cells was glued to the microsensor at a distance of $1 \mathrm{~cm}$ from the tip. Prior to use, it was necessary to precondition the biosensor in $0.1 \mathrm{mM}$ glucose solution for at least $2 \mathrm{~h}$ to activate the cells. The microbial biosensor responds to ADOC by oxygen consumption. The extent of oxygen consumption calculated from the linear decrease of the time-dependent current signal of the electrode (kinetic measurement) serves as a measure of the amount of ADOC. The $90 \%$ response time of the microbial biosensor varied between 1 and $5 \mathrm{~min}$. The calibration of the biosensor was carried out at room temperature $\left(20\right.$ to $\left.22^{\circ} \mathrm{C}\right)$ in oxygen saturated mineral salt medium supplemented with different concentrations of glucose. Relative amounts of ADOC were measured as glucose equivalents in $0.2 \mu \mathrm{m}$ pore size filtered and oxygen saturated pore waters. ADOC measurements of all samples were performed with the same biosensor. After measuring about 20 samples, the biosensor was allowed to rest in a solution of low carbon concentration ( $0.01 \mathrm{mM}$ glucose) for $12 \mathrm{~h}$ to avoid possible organic carbon overloading due to high carbon concentrations of standard solutions and samples.

Microbial biomass. Microbial biomass parameters were assayed in selected sediment horizons $(0-1,4-5$ and $9-10 \mathrm{~cm})$. For the estimation of total living biomass, ATP concentrations were determined. Three replicates of $0.25 \mathrm{~cm}^{3}$ sediment with increasing concentrations of internal standards of ATP were extracted in $25 \mathrm{ml}$ of boiling $2 \mathrm{mM}$ EDTA/20 mM Tris-buffer (Karl 1993). After an extraction period of $15 \mathrm{~min}$, the supernatants were centrifuged; $0.1 \mathrm{ml}$ of firefly lantern extract (purified luciferine/luciferase, LUMIT-PM) was added to an equal amount of extract. Bioluminescence of the samples was measured with a LUMIT Biocounter M 1500. The extraction efficiency of ATP was calculated for the individual sediment horizons using 3 concentrations of ATP as internal standards. Extraction efficiency of ATP varied between 20 and $100 \%$ and was strongly related to the mud content of the sediments. For conversion of ATP to cellular carbon, the ratio of 250 normally applied for sediments was used (Karl 1980). For the estimation of total microbial biomass, phospholipids were measured spectrophotometrically according to Findlay et al. (1989). A conversion factor of $1 \mathrm{mg}$ of $\mathrm{C}$ per 100 nmol of phospholipids (measured as lipid phosphate) was used to calculate microbial biomass (Bott \& Kaplan 1985). Photoautotrophic biomass was estimated from measurements of chl a. By adding $10 \mathrm{ml}$ of $96 \%$ ethanol, chl a was extracted in 5 replicates of $0.5 \mathrm{~cm}^{3}$ sediment. Extracts were acidified with $120 \mu \mathrm{l}$ of $1 \mathrm{~N} \mathrm{HCl}$ to determine phaeopigments. Pigment concentrations were analysed spectrophotome- 
trically at wavelengths of 665 and $750 \mathrm{~nm}$, respectively, before and after acidification (HELCOM 1988). Chl a concentrations were converted to autotrophic biomass carbon assuming a conversion factor of 40 proposed for microphytobenthos (Cammen 1991) and often used for algae in general (Herbert 1990). Bacterial abundance was determined by epifluorescence microscopy using acridine orange (Meyer-Reil 1983). Cell numbers were converted to bacterial biomass carbon by using sediment-specific factors of $1.6 \times$ $10^{-8} \mu \mathrm{g} \mathrm{C}$ per cell for sand and $2.0 \times 10^{-8} \mu \mathrm{g} \mathrm{C}$ for (slightly) muddy sand (Meyer-Reil 1993).

Enzymatic activity. Microbial enzymatic decomposition was analysed in selected sediment horizons (0-1, 4-5 and 9-10 cm). Five $\mathrm{cm}^{3}$ of sediment were diluted 1:15 with phosphate buffer ( $\mathrm{pH} 7.8$ ). Duplicate aliquots ( $2 \mathrm{ml}$ ) of the slurry were supplied with $40 \mu \mathrm{l}$ of the model substrate fluorescein diacetate $(5 \mathrm{mM})$ hydrolysed unspecifically by esterases (Köster et al. 1997). The release of the fluorescent dye was analysed spectrofluorometrically at $370 \mathrm{~nm}$ excitation and $410 \mathrm{~nm}$ emission. Enzymatic decomposition rates were calculated from the linear part of time-dependent activity curves.

\section{RESULTS}

\section{Sediment characterization}

Generally, sediments are classified by geologists according to the contribution of the fraction $<63 \mu \mathrm{m}$ (defined as mud content) to the dry weight of total sediment (Figge et al. 1980). B. W. Flemming (pers. comm.) differentiates between 6 sediment categories: sand $(<5 \%)$, slightly muddy sand (5-25\%), muddy sand $(25-50 \%)$, sandy mud (50-75\%), slightly sandy mud $(75-95 \%)$, and mud (>95\%). According to this classification, the sediments sampled at the locations in the Rassower Strom can be attributed to 3 sediment categories. Surface sediments (0 to $1 \mathrm{~cm}$ ) of Stns 3 and 4 located in water depths of 0.5 and $1.0 \mathrm{~m}$, respectively, with a mud content of less than $2 \%$ consisted of sand (Group I). Stns 2, 7 and 8 (water depths between 2.1 and $4.3 \mathrm{~m}$ ) with a mud content of 7 to $17 \%$ were characterized as slightly muddy sand (Group II). Stns 1, 5 and 6 (water depths between 3.5 and $4.5 \mathrm{~m}$ ) with a mud content of 27 to $42 \%$ comprised muddy sand (Group III; Table 1, Fig. 2). Generally, sand and slightly muddy sand were characterized by relatively homogenous depth profiles of mud content, whereas changes in mud content were more pronounced in muddy sand sediments. It should be noted that the subsurface sediments of Stns 1 and 8 revealed sediment characteristics differing from those at the surface. The muddy sand surface sediments of Stn 1 were sublayered by a more sandy layer $(1$ to $3 \mathrm{~cm}$ ), and the slightly muddy sand sediments of Stn 8 by sand (Fig. 2).

Differences in sediment type were also mirrored by dry bulk densities (dry mass of sediment in a given volume of sediment) which ranged between 0.60 and $1.46 \mathrm{~g} \mathrm{~cm}^{-3}$ in the different sediments investigated. Sands with low pore volume revealed higher dry bulk densities than muddy sands with high pore volume. In the same way, increases in dry bulk density were associated with decreases in water content. In the sandy

Table 1. Sediment characteristics $(0-1 \mathrm{~cm}$ horizon) of the 8 stations investigated in the Rassower Strom. The stations were grouped according to increasing mud content (percentage of the fraction $<63 \mu \mathrm{m}$ to total sediment dry weight). Values in parentheses indicate ranges of elemental contents

\begin{tabular}{|c|c|c|c|}
\hline $\begin{array}{l}\text { Group: } \\
\text { Sediment type: }\end{array}$ & $\begin{array}{c}\text { I } \\
\text { Sand }\end{array}$ & $\begin{array}{c}\text { II } \\
\text { Slightly muddy sand }\end{array}$ & $\begin{array}{c}\text { III } \\
\text { Muddy sand }\end{array}$ \\
\hline Stn & 3,4 & $2,7,8$ & $1,5,6$ \\
\hline Water depth (m) & $0.5-1.0$ & $2.1-4.3$ & $3.5-4.5$ \\
\hline Fraction $<63 \mu \mathrm{m}(\%)$ & $1-2$ & $7-17$ & $27-42$ \\
\hline Water content (\%) & $26-28$ & $32-36$ & $44-55$ \\
\hline $\begin{array}{l}\text { Organic carbon }\left(\mathrm{mg} \mathrm{cm}^{-3}\right) \\
(\% \mathrm{dw})\end{array}$ & $\begin{array}{l}3.3-4.0 \\
(0.3)\end{array}$ & $\begin{array}{c}4.7-6.1 \\
(0.4-0.6)\end{array}$ & $\begin{array}{l}9.6-12.9 \\
(1.5-1.6)\end{array}$ \\
\hline $\begin{array}{l}\text { Nitrogen }\left(\mathrm{mg} \mathrm{cm}^{-3}\right) \\
(\% \mathrm{dw})\end{array}$ & $\begin{array}{l}0.72-0.86 \\
(0.05-0.06)\end{array}$ & $\begin{array}{l}0.77-0.95 \\
(0.07-0.09)\end{array}$ & $\begin{array}{c}1.35-1.43 \\
(0.17-0.22)\end{array}$ \\
\hline $\begin{array}{l}\text { Total phosphorus }\left(\mu \mathrm{g} \mathrm{cm}^{-3}\right) \\
(\% \mathrm{dw})\end{array}$ & $\begin{array}{c}199-212 \\
(0.015)\end{array}$ & $\begin{array}{c}248-297 \\
(0.025)\end{array}$ & $\begin{array}{c}280-352 \\
(0.046-0.052)\end{array}$ \\
\hline $\begin{array}{l}\text { Organic phosphorus }\left(\mu \mathrm{g} \mathrm{cm}^{-3}\right) \\
(\% \mathrm{dw})\end{array}$ & $\begin{array}{c}25-63 \\
(0.002-0.004)\end{array}$ & $\begin{array}{c}23-40 \\
(0.002-0.004)\end{array}$ & $\begin{array}{c}21-91 \\
(0.003-0.013)\end{array}$ \\
\hline $\mathrm{C}: \mathrm{N}$ ratio (molar) & 5.4 & $7.0-8.5$ & $8.3-10.6$ \\
\hline $\mathrm{N}: \mathrm{P}$ ratio (molar) & $30-64$ & $47-90$ & $35-149$ \\
\hline
\end{tabular}



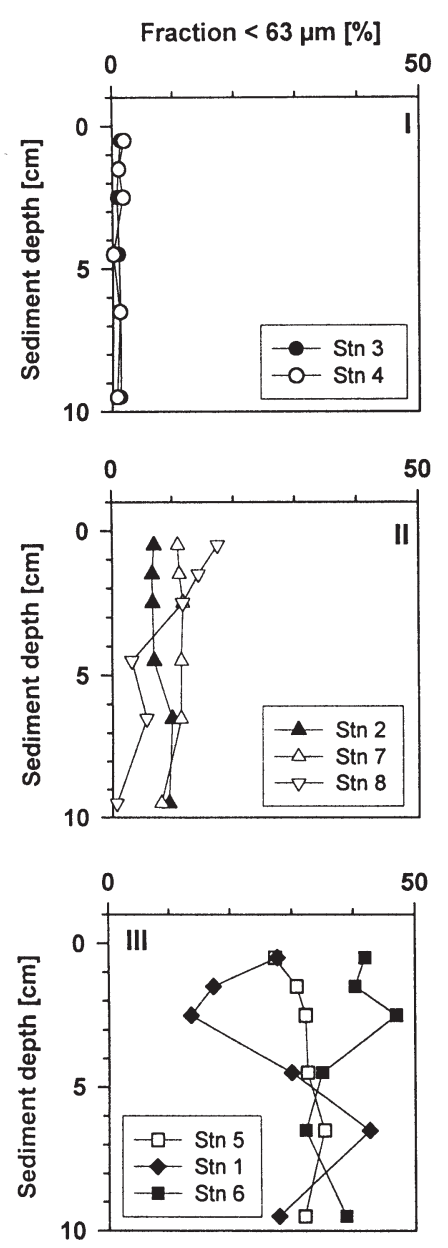
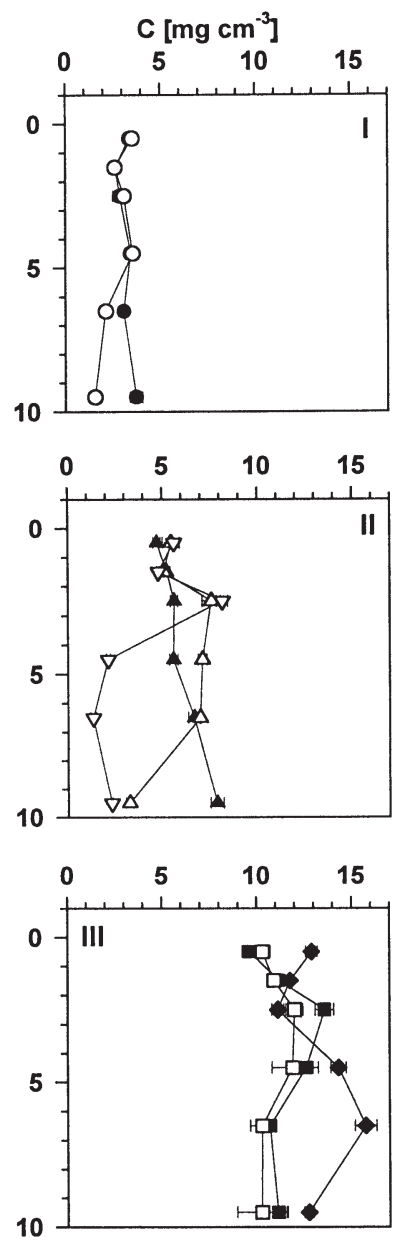
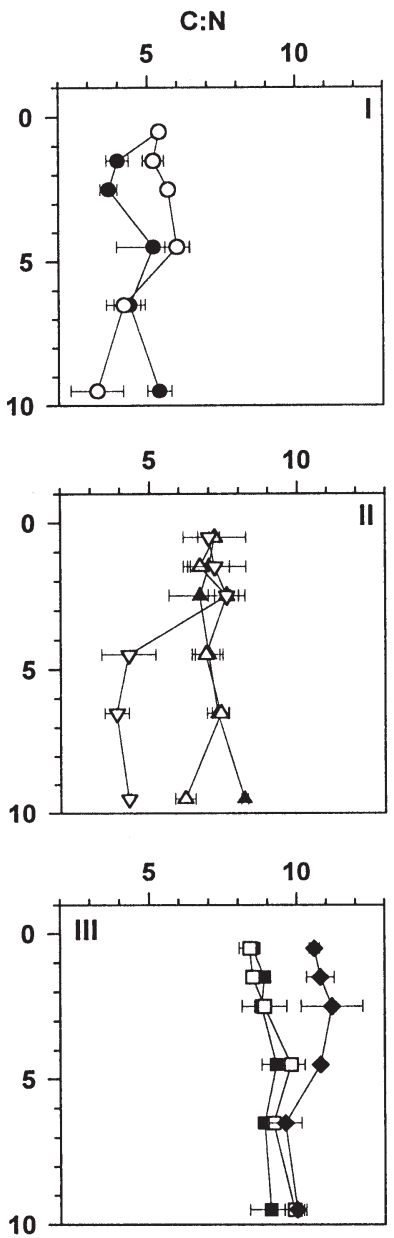

Fig. 2. Mud content (percentage of the fraction $<63 \mu \mathrm{m}$ to total sediment dry weight), organic carbon (C), and the ratio of carbon to nitrogen $(\mathrm{C}: \mathrm{N})$ in sediment profiles of the 8 stations sampled in the Rassower Strom. The stations were grouped according to the sediment type. I: sand, II: slightly muddy sand, III: muddy sand. Horizontal bars represent standard errors of the mean

surface sediments of Stns 3 and 4, the water content varied between 26 and $28 \%$, in slightly muddy sand sediments (Stns 2, 7 and 8) between 32 and 36\%, and in muddy sand sediments (Stns 1, 5 and 6) between 44 and $55 \%$ (Table 1). Sediment depth profiles of the fraction $<63 \mu \mathrm{m}$ paralleled those of the water content (Fig. 2).

Microphytobenthos colonized sandy sediments (Stns 3 and 4); they were green-brown coloured at the surface and covered by patchy distributed flocculent material. Slightly muddy sands of Stns 7 and 8 were densely colonized by macrophytes (Characeae, Potamogetonaceae), whereas Stn 2 revealed high abundances of endobenthic macrofauna. Grey coloured muddy sand sediments were generally less colonized by macrofauna. Muddy sand sediments of Stn 1 were covered by filamentous algae (Pilayella sp.) and macrophytes (Potamogetonaceae).

\section{Sedimentary carbon, nitrogen and phosphorus}

Concentrations of organic carbon, nitrogen, and phosphorus reflected the classification of the sediments based on the sediment fraction $<63 \mu \mathrm{m}$ (Table 1, Fig. 2). In surface horizons of sandy sediments (Stns 3 and 4) concentrations of organic carbon varied between 3.3 and $4.0 \mathrm{mg} \mathrm{cm}^{-3}$ (corresponding to $0.3 \% \mathrm{dw}$ [dry weight]), in slightly muddy sand sediments (Stns 2,7 and 8 ) between 4.7 and $6.1 \mathrm{mg} \mathrm{cm}^{-3}$ (0.4 to $0.6 \%$ $\mathrm{dw}$ ), and in muddy sand sediments (Stns 1, 5 and 6) between 9.6 and $12.9 \mathrm{mg} \mathrm{cm}^{-3}$ (1.5 to $1.6 \% \mathrm{dw}$ ). Maximum organic carbon concentrations of $15.8 \mathrm{mg} \mathrm{cm}^{-3}$ $(1.8 \% \mathrm{dw})$ were reached in intermediate horizons of muddy sand sediments of Stn 1 covered by macrophytes (Fig. 2). Nitrogen concentrations (0.7 to $1.4 \mathrm{mg}$ $\mathrm{cm}^{-3}$ ) in surface sediments were almost 1 order of magnitude lower than organic carbon concentrations. 

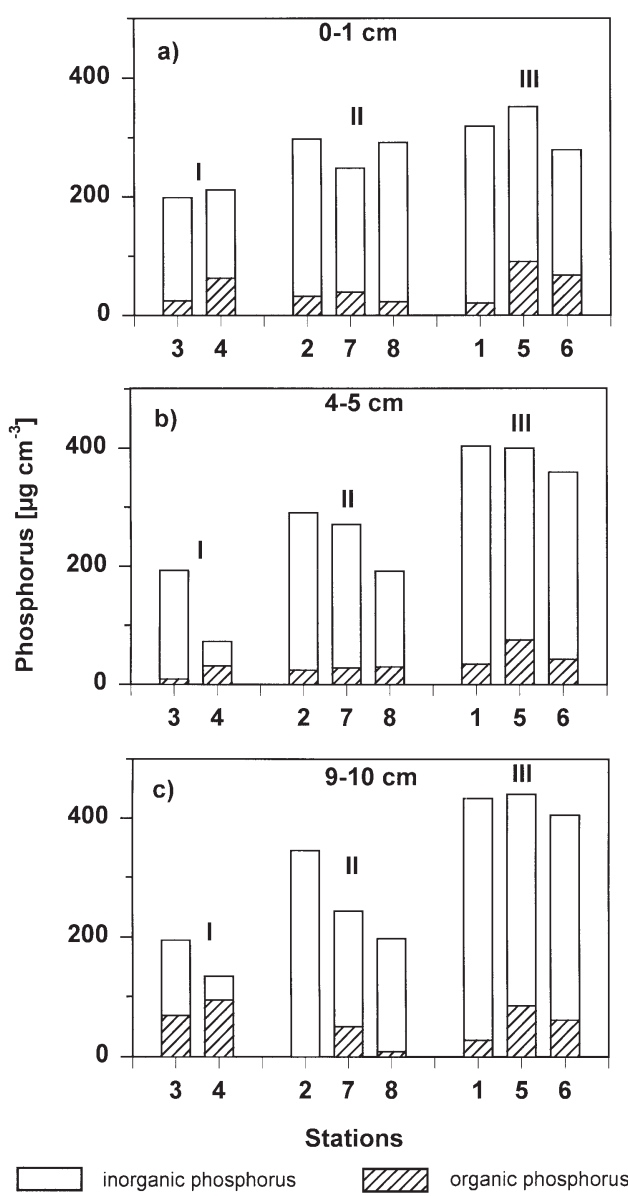

Fig. 3. Inorganic and organic phosphorus concentrations in selected sediment horizons $(0-1,4-5,9-10 \mathrm{~cm})$ of the 8 stations sampled in the Rassower Strom. The stations were grouped according to the sediment type

Parallel to carbon, concentrations of nitrogen generally increased with increasing mud content (Table 1).

Total phosphorus concentrations in surface sediments also reflected differences in mud content. Phosphorus slightly increased from $199-212 \mu \mathrm{g} \mathrm{\textrm {cm } ^ { - 3 }}$ in sand sediments to $248-297 \mu \mathrm{g} \mathrm{cm}^{-3}$ in slightly muddy sand and to $280-352 \mu \mathrm{g} \mathrm{cm}{ }^{-3}$ in muddy sand. Generally, variations of organic carbon and nitrogen were paralleled by total phosphorus concentrations. Organic phosphorus concentrations ranged between 21 and 91 $\mu \mathrm{g} \mathrm{cm} \mathrm{cm}^{-3}$ in surface sediments and accounted for 7 to $26 \%$ of total phosphorus. Relatively high organic phosphorus concentrations were found in muddy sand surface sediments (Stns 5 and 6; concentrations of 91 and $68 \mu \mathrm{g} \mathrm{cm}^{-3}$, respectively) and subsurface sandy sediments (Stns 3 and 4; concentrations of 68 and $94 \mu \mathrm{g}$ $\mathrm{cm}^{-3}$, respectively; Table 1, Fig. 3).

Ratios between carbon $(\mathrm{C})$, nitrogen $(\mathrm{N})$ and phosphorus $(\mathrm{P})$ reflect the composition of the organic mate- rial. Carbon poor sandy surface sediments of Stns 3 and 4 showed lowest C:N molar ratios of 5.4 and N:P molar ratios of 30 to 64 , pointing to a depletion of organic carbon and a relative enrichment of nitrogen and phosphorus. Slightly muddy sand surface sediments of Stns 2, 7 and 8 revealed C:N ratios between 7.0 and 8.5 and $\mathrm{N}: \mathrm{P}$ ratios between 47 and 90 . In sediments of Stn 8, however, the more sandy character of the subsurface horizons was reflected by extremely low C:N ratios (3.9 to 4.3). Muddy sand surface sediments of Stns 1, 5 and 6 with comparatively high organic carbon, nitrogen and phosphorus concentrations were characterized by relatively high $\mathrm{C}: \mathrm{N}$ ratios (8.3 to 10.6) and N:P ratios (35 to 149) indicating that nitrogen and phosphorus were preferentially consumed over carbon (Table 1, Fig. 2).

\section{Dissolved inorganic and organic carbon}

DIC concentrations in pore waters ranged between 4.9 and $60.2 \mu \mathrm{g} \mathrm{cm}^{-3}$. With the exception of Stn 6, concentrations of DIC measured in the overlying water (21.4 to $27.1 \mu \mathrm{g} \mathrm{cm}^{-3}$ ) were higher than those in surface sediments. Generally, there was a tendency for increasing concentrations of DIC with increasing mud content. Enrichments of DIC were detected in subsurface horizons of Stns 2 (slightly muddy sand) and 6 (muddy sand colonized by macrofauna; Fig. 4).

DOC concentrations in pore waters ranged between 5.3 and $77.8 \mu \mathrm{g} \mathrm{cm}^{-3}$, comprising 0.2 to $0.6 \%$ of the TOC. Generally, DOC concentrations increased from sandy towards muddy sand sediments. In subsurface slightly muddy sand sediments of Stn 2 colonized by macrofauna, DOC concentrations were comparatively high (up to $45 \mu \mathrm{g} \mathrm{cm} \mathrm{cm}^{-3}$ ). Peaks of DOC (77.8 and $41.2 \mu \mathrm{g} \mathrm{cm}^{-3}$, respectively) were mostly pronounced in muddy sand surface sediments of Stns 1 and 5. The former location was intensively colonized by macrophytes (Fig. 4).

Depth profiles of ADOC generally paralleled those of DOC. High ADOC concentrations of up to $20.8 \mu \mathrm{g} \mathrm{cm}^{-3}$ (glucose carbon equivalents) were found in sand and slightly muddy sand at the sediment surface. However, in muddy sand sediments of Stns 1, 5 and 6, high DOC concentrations at the surface were not mirrored by an accumulation of ADOC. Highest ADOC concentrations with a maximum of $35.2 \mu \mathrm{g} \mathrm{cm}^{-3}$ were observed in bioturbated subsurface sediments of Stn 2 (Fig. 4).

\section{Microbial biomass and activity}

Phospholipids, ATP, chl $a$, and bacterial numbers were analysed to characterize biomass carbon. Micro- 

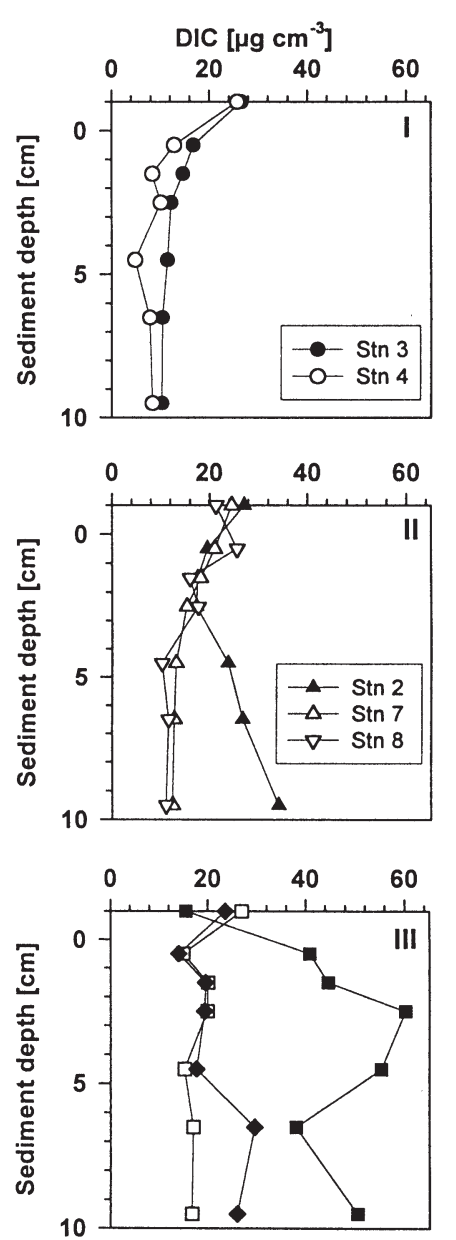
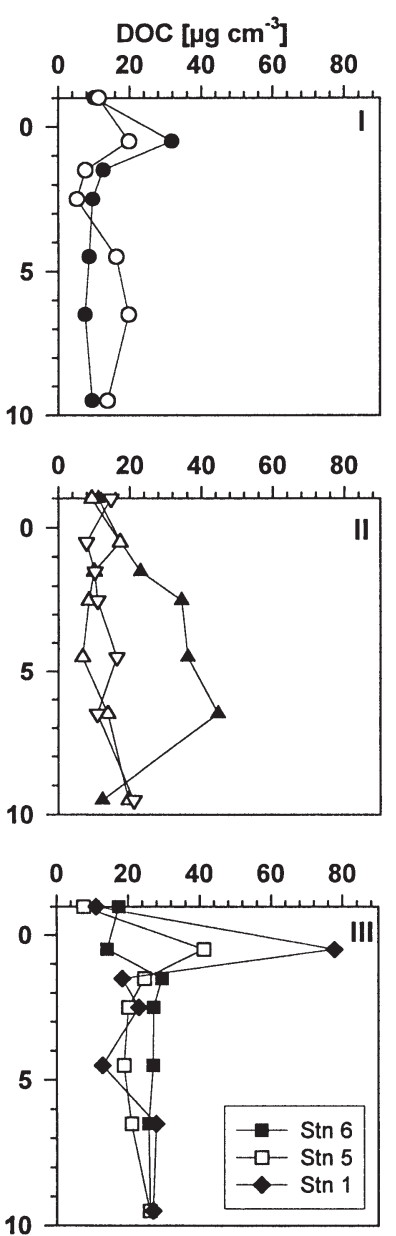
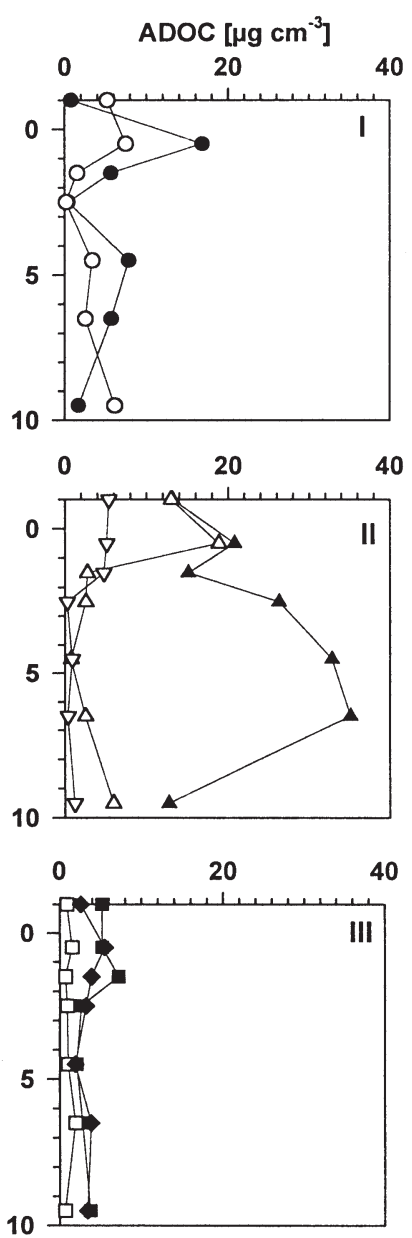

Fig. 4. Concentrations of dissolved inorganic carbon (DIC), dissolved organic carbon (DOC), and available dissolved organic carbon (ADOC) in sediment profiles of the 8 stations sampled in the Rassower Strom. The stations were grouped according to the sediment type

bial parameters and extrapolated biomass analysed at selected depth intervals $(0-1,4-5$ and $9-10 \mathrm{~cm})$ of the 8 stations are compiled in Table 2. Generally, highest values occurred in surface sediments, with rapidly decreasing values below the surface.

Concentrations of phospholipids ranged between 60 and $154 \mathrm{nmol} \mathrm{cm}^{-3}$ (corresponding to between 601 and $1536 \mu \mathrm{g} \mathrm{C} \mathrm{cm}^{-3}$ ) in surface sediments and generally decreased with depth. Muddy sand surface sediments revealed maximum phospholipid concentrations (102 to $154 \mathrm{nmol} \mathrm{cm}^{-3}$ ), which were twice as high as those of sandy sediments. ATP concentrations varied considerably in surface sediments (673 to $2843 \mathrm{ng} \mathrm{cm}^{-3}$, corresponding to between 168 and $711 \mu \mathrm{g} \mathrm{C} \mathrm{cm}{ }^{-3}$ ). Concentrations rapidly declined in subsurface sediment horizons. Highest ATP concentrations were observed in sandy surface sediments of Stn 4 characterized by a rich microphytobenthic colonization. Chl a concentrations ranged between 6 and $21 \mu \mathrm{g} \mathrm{cm}^{-3}$ (corresponding to between 227 and $852 \mu \mathrm{g} \mathrm{C} \mathrm{cm}^{-3}$ ) in surface sediments. Overall, more sandy sites (Stns 2, 3, 4, 7 and 8) revealed higher chl a concentrations (12 to $\left.21 \mu \mathrm{g} \mathrm{cm}^{-3}\right)$ than more muddy sites (Stns 1, 5 and 6) with values ranging between 6 and $13 \mu \mathrm{g} \mathrm{cm}^{-3}$. Chl a concentrations of up to $7.7 \mu \mathrm{g} \mathrm{cm}^{-3}$ (corresponding to $308 \mu \mathrm{g} \mathrm{C}$ $\mathrm{cm}^{-3}$ ) occurred below the photic zone, down to a sediment depth of $10 \mathrm{~cm}$. Low levels of phaeopigments were detected in sandy sediments, whereas in sediments with a higher mud content phaeopigments accumulated. Bacterial numbers ranged between $2.4 \times 10^{9}$ and $6.7 \times 10^{9}$ cells cm$^{-3}$ (corresponding to between 38 and $133 \mu \mathrm{g} \mathrm{C} \mathrm{cm}^{-3}$ ) in surface layers and declined to between $0.5 \times 10^{9}$ and $4.7 \times 10^{9}$ cells cm$^{-3}$ (corresponding to between 8 and $93 \mu \mathrm{g} \mathrm{cm}^{-3}$ ) in the 9 to $10 \mathrm{~cm}$ sediment layer. Bacterial numbers and biomass generally increased from sandy to muddy sand sediments.

Microbial enzymatic decomposition (FDA hydrolysis) increased along the mud gradient. In muddy 


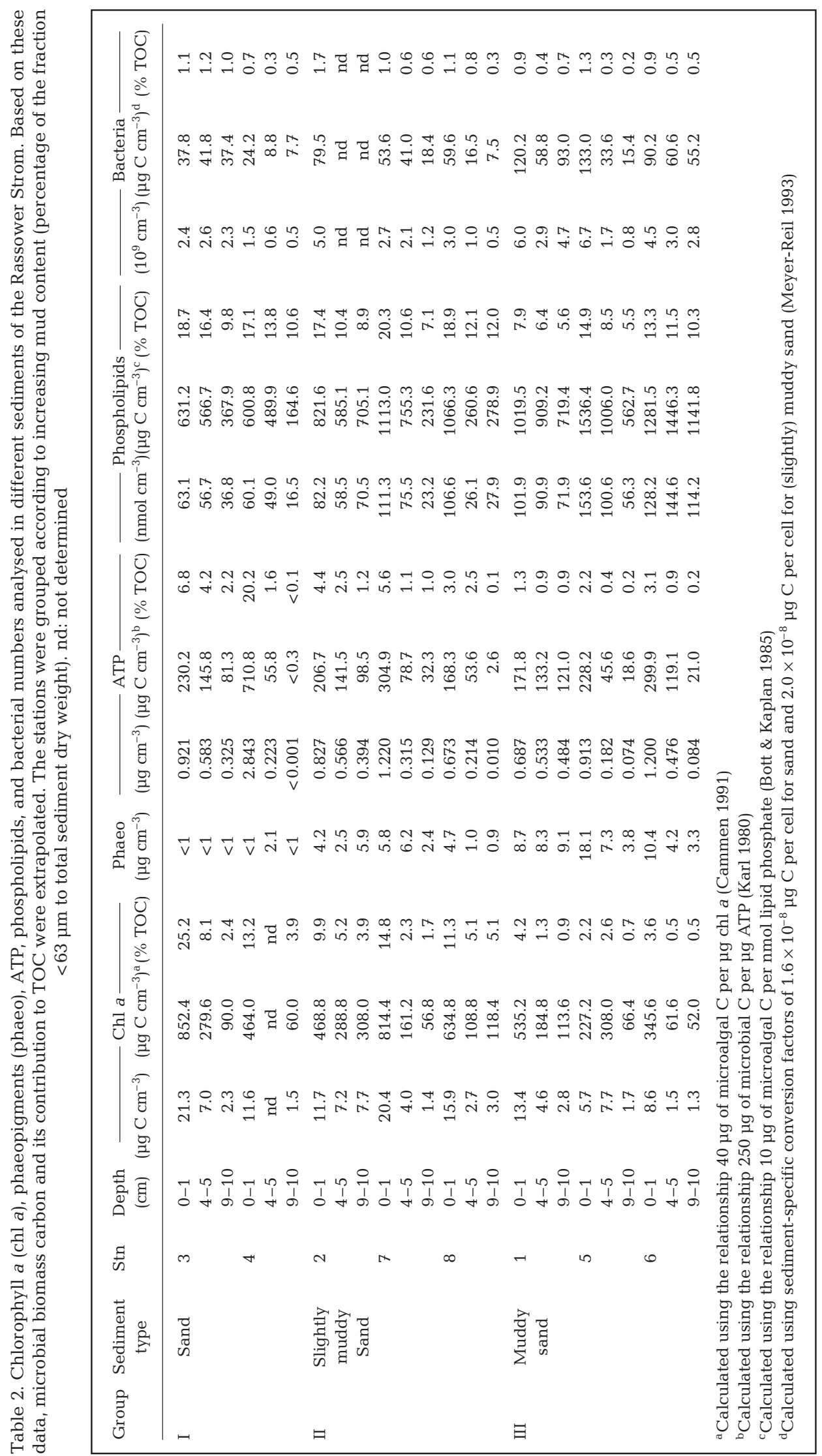



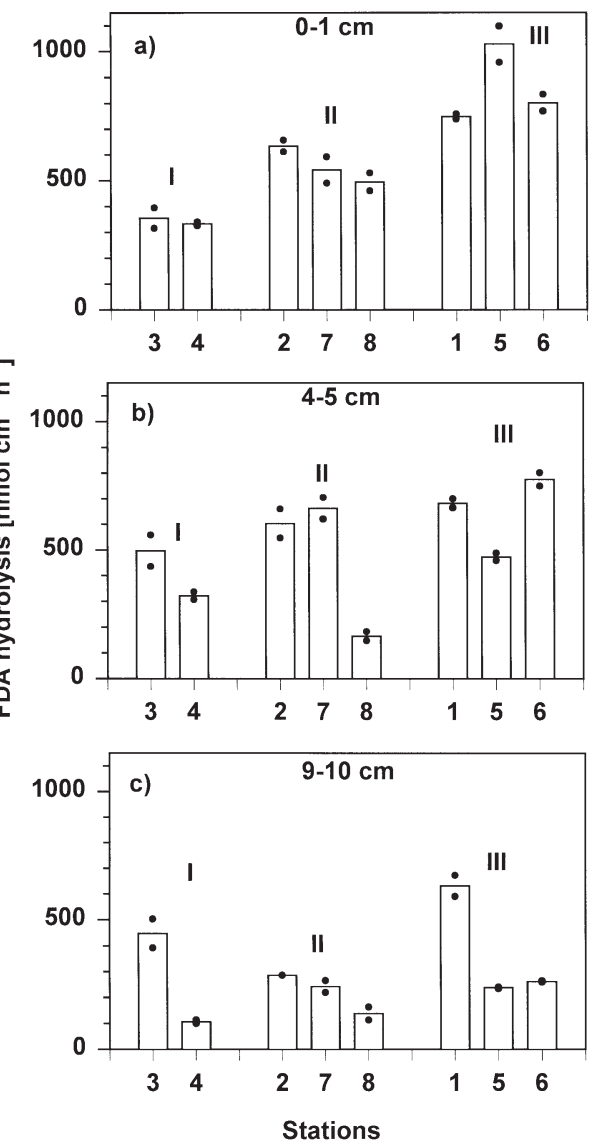

Fig. 5. Enzymatic activity (measured as hydrolysis of the model substrate fluorescein diacetate, FDA) in selected sediment horizons $(0-1,4-5,9-10 \mathrm{~cm})$ of the 8 stations sampled in the Rassower Strom. The stations were grouped according to the sediment type. $(\bullet)$ Individual values of duplicate measurements

sand surface sediments enzymatic degradation rates were about twice to 3 times as high as those in sandy sediments (748 to 1029 and 334 to $356 \mathrm{nmol} \mathrm{cm}{ }^{-3} \mathrm{~h}^{-1}$, respectively). With increasing sediment depth, enzymatic activity generally decreased (Fig. 5).

\section{DISCUSSION}

\section{Sediment characterization}

Data based on measurements of mud content (percentage of the fraction $<63 \mu \mathrm{m}$ to total sediment dry weight), water content, and quantity and quality of organic matter clearly reflected the differentiation of the sediments into 3 groups defined as sand, slightly muddy sand, and muddy sand. Increases in mud content were associated with decreases in dry bulk density, increases in water content, and organic matter concentration (Table 1). In Fig. 6a TOC content (percentage related to dry weight of sediments) is plotted versus concentration (volume-specific dry mass). A linear relationship between carbon content and concentration was found for sand and slightly muddy sand with low water contents (less than $36 \%$ ). In muddy sand sediments with higher water contents $(26$ to $55 \%$ ), relatively high TOC contents were associated with comparably low concentrations. Similar relationships were obtained plotting organic carbon concentration versus mud content (Fig. 6b). From the nonlinear relationship between organic carbon content and concentration, it becomes obvious that data from different sediments have to be compared on a volume
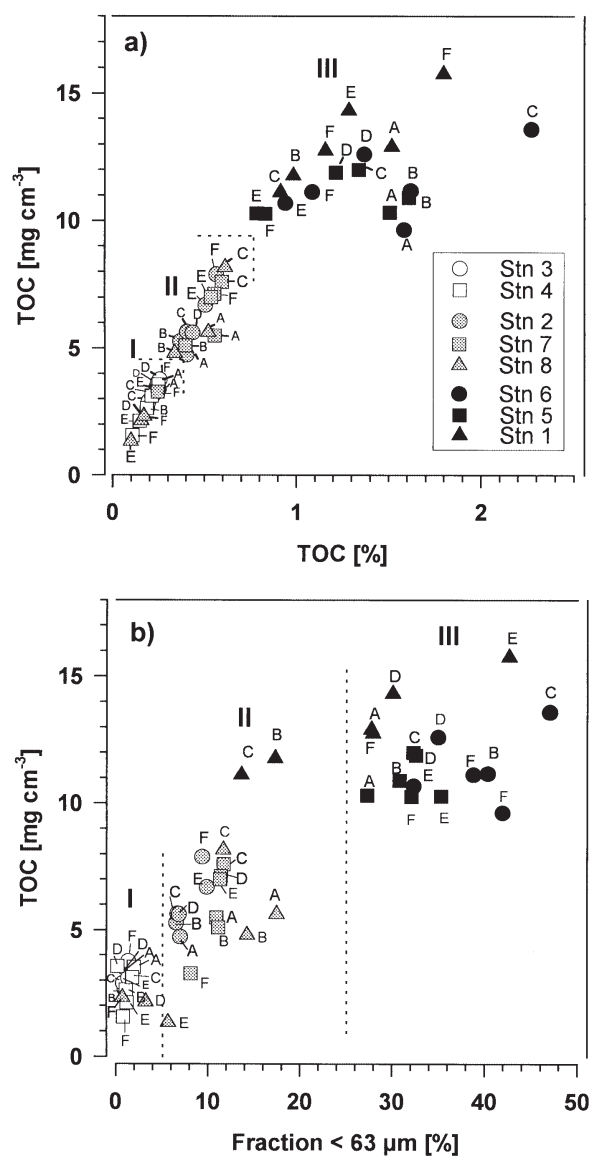

Fig. 6. Relationships between concentration and content of organic carbon (a) and between organic carbon concentration and mud content expressed as percentage of the fraction $<63 \mu \mathrm{m}$ to total sediment dry weight (b) in sediments of the 8 stations sampled in the Rassower Strom. Letters refer to different sediment horizons $(\mathrm{A}=0-1 \mathrm{~cm}, \mathrm{~B}=1-2 \mathrm{~cm}, \mathrm{C}=$ $2-3 \mathrm{~cm}, \mathrm{D}=4-5 \mathrm{~cm}, \mathrm{E}=6-7 \mathrm{~cm}, \mathrm{~F}=9-10 \mathrm{~cm})$. Correlations between concentration and content of organic carbon $(y=$ $11.9 x+0.5, \mathrm{r}=0.976, \mathrm{p}<0.001, \mathrm{n}=30$ ) and between organic carbon concentration and mud content $(y=0.3 x+2.6, r=$ $0.710, \mathrm{p}<0.01, \mathrm{n}=30$ ) were given for sandy and slightly muddy sand sediments (Groups I and II) 
Table 3. Pools of total organic carbon (TOC), dissolved inorganic carbon (DIC), dissolved organic carbon (DOC) and available dissolved organic carbon (ADOC) summed up over a depth of $10 \mathrm{~cm}$ in sediments of the 8 stations investigated in the Rassower Strom. The contribution of the different carbon pools is given as percentage of TOC and DOC. The stations were grouped according to increasing mud content (percentage of the fraction $<63 \mu \mathrm{m}$ to total sediment dry weight)

\begin{tabular}{|c|c|c|c|c|c|c|c|c|}
\hline Group & $\begin{array}{l}\text { Sediment } \\
\text { type }\end{array}$ & Stn & $\begin{array}{c}\text { TOC } \\
\left(\mathrm{mg} \mathrm{cm}^{-2}\right)\end{array}$ & $\begin{array}{c}\text { DIC } \\
\left(\mu \mathrm{g} \mathrm{cm}^{-2}\right)\end{array}$ & $\begin{array}{c}\text { DOC } \\
\left(\mu \mathrm{g} \mathrm{cm}^{-2}\right)\end{array}$ & $\begin{array}{c}\text { DOC } \\
(\% \text { TOC })\end{array}$ & $\begin{array}{c}\mathrm{ADOC} \\
\left(\mu \mathrm{g} \mathrm{cm}^{-2}\right)\end{array}$ & $\begin{array}{c}\text { ADOC } \\
(\% \text { DOC })\end{array}$ \\
\hline I & Sand & $\begin{array}{l}3 \\
4\end{array}$ & $\begin{array}{l}32.5 \\
26.4\end{array}$ & $\begin{array}{r}119.9 \\
82.9\end{array}$ & $\begin{array}{l}115.1 \\
145.4\end{array}$ & $\begin{array}{l}0.4 \\
0.6\end{array}$ & $\begin{array}{l}64.8 \\
37.6\end{array}$ & $\begin{array}{l}56.3 \\
25.8\end{array}$ \\
\hline II & $\begin{array}{c}\text { Slightly } \\
\text { muddy sand }\end{array}$ & $\begin{array}{l}2 \\
7 \\
8\end{array}$ & $\begin{array}{l}62.2 \\
60.3 \\
35.0\end{array}$ & $\begin{array}{l}246.4 \\
146.0 \\
140.4\end{array}$ & $\begin{array}{l}301.3 \\
128.2 \\
137.3\end{array}$ & $\begin{array}{l}0.5 \\
0.2 \\
0.4\end{array}$ & $\begin{array}{r}267.6 \\
58.3 \\
21.1\end{array}$ & $\begin{array}{l}88.8 \\
45.5 \\
15.4\end{array}$ \\
\hline III & Muddy sand & $\begin{array}{l}1 \\
5 \\
6\end{array}$ & $\begin{array}{l}134.9 \\
109.2 \\
115.3\end{array}$ & $\begin{array}{l}224.1 \\
171.2 \\
482.4\end{array}$ & $\begin{array}{l}280.4 \\
238.6 \\
255.3\end{array}$ & $\begin{array}{l}0.2 \\
0.2 \\
0.2\end{array}$ & $\begin{array}{l}37.5 \\
13.0 \\
40.5\end{array}$ & $\begin{array}{r}13.4 \\
5.5 \\
15.9\end{array}$ \\
\hline
\end{tabular}

basis to gain meaningful interpretations (see Bird \& Duarte 1989, Delafontaine et al. 1996).

In the present study, organic poor sand sediments revealed relatively low $\mathrm{C}: \mathrm{N}$ and $\mathrm{N}: \mathrm{P}$ molar ratios which may indicate easily degradable organic material of a high nutritional value relatively rich in nitrogen and phosphorus. This was underlined by the relatively high ratios of chl a to phaeopigments. In contrast, organic rich muddy sand sediments showed high $\mathrm{C}: \mathrm{N}$ and $\mathrm{N}: \mathrm{P}$ ratios, which pointed to more refractory material relatively rich in carbon and relatively poor in nitrogen and phosphorus. Ratios of chl a to phaeopigments in muddy sand sediments were much lower compared to sandy sediments (see below). C:N:P ratios varied between 164:30:1 and 1581:149:1 in surface horizons of the different sediment types. Deviations from the Redfield ratio were mostly pronounced in the fine-grained muddy sand sediments characterized by enhanced enzymatic degradation rates which underline the importance of the decomposition of higher molecularweight organic matter at these sites. Findings of other studies support the fact that ratios of carbon, nitrogen, and phosphorus (e.g. Ingall \& van Cappellen 1990, Middelburg et al. 1996, Raimbault et al. 1999) as well as ratios of chl a to phaeopigments (e.g. Barlow et al. 1995, Cariou-Le Gall \& Blanchard 1995, Lucas \& Holligan 1999) mirror the diagenetic state and the quality of particulate organic matter.

\section{Size and composition of sedimentary carbon pools}

From summing up concentrations of organic carbon in sediments of the Rassower Strom over a depth of $10 \mathrm{~cm}$, it became obvious that TOC pools were smallest in sandy sediments and increased about 4-fold towards muddy sand sediments (compare Balzer et al. 1987, Holmer 1996, Köster et al. 1997, Rieling 1999). Sedi- mentary DIC and DOC pools were similar in size and increased from sand towards muddy sand. Despite its small contribution, the DOC pool (less than $1 \%$ of TOC) is especially important (Table 3 ). The sedimentary DOC pool is mainly supplied by exudation of micro- and macroalgae, excretion of macrozoobenthos, and lysis of organisms (e.g. Ducklow \& Carlson 1992). An additional unknown part of the DOC may be adsorbed to inorganic and organic particles, where it may serve as storage of decomposable carbon (Keil et al. 1994). Little is known about the composition and availability of DOC in marine waters and sediments. A long-held perception based on chemical analyses of individual compounds was that the overwhelming portion of DOC in seawater consists of refractory, high molecular weight humic-like material with little dynamics in biological cycling (McCarthy et al. 1993). Later studies showed that labile compounds comprised a higher portion of DOC than previously thought. It is still under discussion whether low molecular weight material such as sugars and organic acids or high molecular weight compounds such as polysaccharides are preferentially utilized by microorganisms (Amon \& Benner 1994, 1996, Volk et al. 1997).

Especially the determination of the easily assimilable fraction of the DOC (ADOC; Neudörfer \& Meyer-Reil 1997 ) is of great importance, because this fraction serves as the main carbon source for microheterotrophs. Since the chemical analysis of the composition of DOC is very time consuming and its availability to microorganisms remains uncertain, bioassays have been applied to estimate ADOC (compare literature survey by Neudörfer \& Meyer-Reil 1997). To our knowledge only 1 approach was undertaken to measure ADOC in sediments by measuring the growth of pure cultures of bacteria in pore water or sediment extracts (Nedwell 1987). However, bioassays require incubation times of several days and suffer from 
methodological limitations (e.g. manipulation of samples, sample volume, bottle effect). Recently, a microbial biosensor for the determination of ADOC in sediments has been developed consisting of an oxygen microelectrode with microorganisms attached to the tip. The oxygen consumption of the microorganisms as a response to the available organic carbon serves as a measure of ADOC (Neudörfer \& Meyer-Reil 1997). The microbial biosensor allows the small-scale measurement of $\mathrm{ADOC}_{\text {; }}$ the response is sensitive and rapid. However, it has to be considered that ADOC is defined with respect to the metabolic activities of the test organisms chosen and the carbon source used as standard. It has to be pointed out that the ADOC concentrations represent the net result of liberation and consumption processes at the time of sampling. Furthermore, measurements of ADOC with the microbial biosensor have been restricted to aerobic conditions until now. In the literature it is still controversial as to whether DOC of anoxic pore waters is influenced during exposure to atmospheric oxygen. Orem \& Gaudette (1984) reported quantitative and structural changes in DOC in anoxic pore waters following oxidation. However, our own investigations revealed differences of less than $10 \%$ in DOC concentrations of pore waters treated aerobically and anaerobically (see 'Materials and methods').

In this study, ADOC concentrations varied considerably upon sediment properties and benthic colonization. Higher concentrations of DOC were not necessarily reflected by increasing concentrations of ADOC. Pools of ADOC calculated per $\mathrm{cm}^{2}$ down to a sediment depth of $10 \mathrm{~cm}$ imply that between 6 and $89 \%$ of the DOC pool existed in the form of ADOC. Contrary to the pool sizes of TOC and DOC, the availability of DOC was highest in sandy and slightly muddy sand sediments (between 15 and $89 \%$ of DOC) and lowest in muddy sand sediments (between 6 and $16 \%$ of DOC; Table 3).

Enhanced ADOC concentrations (between 38 and $53 \%$ of DOC) found at the surface of brown-green sandy sediments were obviously due to the liberation of primary produced material by microphytobenthos. Low ADOC concentrations (between 4 and $37 \%$ of DOC) found in muddy sand surface sediments mainly colonized by heterotrophic organisms may be explained by the restricted supply of freshly produced, labile organic material. This hypothesis is supported by the observation of relatively high $\mathrm{C}: \mathrm{N}$ ratios, low chl a to phaeopigment ratios, and enhanced enzymatic decomposition rates of organic material in these sediments. Sediments colonized by Characeae revealed an enrichment of ADOC in surface sediments as was also the case in subsurface sediments inhabited by a rich infauna. Surprisingly, sediments colonized by Potamo- getonaceae revealed no enhanced DOC concentrations, although it is well known from the literature that macrophytes contribute to the organic matter pool by the release of dissolved organic compounds (e.g. Moriarty et al. 1986, Boschker et al. 1999, Hansen \& Lomstein 1999).

\section{Microbial biomass and its relationships with sedi- ment properties and availability of organic carbon}

In the present study phospholipids and bacterial numbers (independent of the physiological state of the organisms) were used to estimate total microbial and bacterial biomass in different sediments of the Rassower Strom. In contrast, the biomass indicators ATP and chl a were considered to be related to photoautotrophic and active microbial biomass. Phospholipid, ATP, and chl a based estimates of microbial biomass (in terms of carbon) in sediments of the Rassower Strom generally comprised the same order of magnitude. Bacterial biomass accounted for less than $10 \%$ of total phospholipid based microbial biomass (Table 2). However, the ratios of the different biomass indicators in surface horizons of sandy, slightly muddy sand, and muddy sand sediments varied. This can be interpreted in terms of a different contribution of active, photoautotrophic, and bacterial biomass, respectively, to total microbial biomass. In sandy surface sediments microbial biomass could be equally characterized by phospholipids, ATP, and chl $a$, indicating that the microbial community was dominated by photoautotrophic, active biomass. With increasing mud content, phospholipid based total microbial biomass increased, whereas the contribution of photoautotrophic (chl a based) and active (ATP based) biomass to total biomass decreased to 31 and $18 \%$, respectively. However, bacterial biomass increased along the mud gradient from 5 to $9 \%$ of total microbial biomass, indicating the importance of bacteria in muddy sand sediments with a limited supply of easily available organic carbon.

The extrapolation of concentrations of biomass indicators to carbon depends on the selection of appropriate conversion factors. Conversion factors used in literature may comprise variations of several orders of magnitude, mainly due to taxonomical and physiological differences of the organisms, in the environmental conditions (e.g. temperature, light, nutrient conditions), and in the behaviours of organisms to preservation (Pelegri et al. 1999). To convert concentrations of phospholipids into carbon, variations of a factor of 5 have been reported (Bott \& Kaplan 1985, Findlay et al. 1989). C:ATP ratios range between 140 and 2000 (Herbert 1990). For C:chl a ratios of microalgae, conversion factors between 10 and 150 have been obtained (de 
Jonge \& Colijn 1994, compare also Laws et al. 1983, Andersson \& Rudehäll 1993). The existence of chl $a$ in deeper layers (e.g. de Jonge \& Colijn 1994, Cariou-Le Gall \& Blanchard 1995) also raises the question of its physiological state (active versus inactive; Karl 1986, Sun et al. 1993, de Jonge \& Colijn 1994). Jeffrey \& Hallegraeff (1980) stated that only 50 to $70 \%$ of the spectrophotometrically determined chl a was intact, the remainder was degraded inactive chl a.

Close relationships between phospholipid concentrations and bacterial biomass as well as between ATP and chl a suggest similar structural and physiological features for the corresponding biomass indicators analysed in sediments of the Rassower Strom (Fig. 7a,b). Whereas phospholipid based biomass and bacterial biomass based on cell counts characterize structural components, chl a and ATP concentrations relate more to the physiological state of the organisms (see Atlas \& Bartha 1987). Similar relationships between ATP and chl a were found in studies of Paerl et al. (1976) and Fry \& Humphrey (1978; cited in Fry 1988) whereas other studies also revealed relationships between ATP and phospholipids (Balkwill et al. 1988, Fry 1988, White et al. 1997).

The influence of sediment properties on microbial biomass becomes evident from the relationships between mud content and total (phospholipid based) microbial biomass on the one hand and bacterial biomass on the other (Fig. 8a,b). Generally, with increasing mud content from sandy to muddy sand sediments, total microbial and bacterial biomass increased. Relationships between mud content and biomass were mostly pronounced in surface sediments and weakened in deeper horizons. The positive correlation between mud content and microbial biomass is consistent with other reports of greater biomass in more finegrained sediments (e.g. Meyer-Reil 1986, 1993, Black et al. 1995, Köster et al. 1997). Relating total microbial and bacterial biomass to organic matter $(\mathrm{C}, \mathrm{N})$ revealed relationships similar to those found in earlier studies (e.g. Rublee 1982). Due to preferable colonization of microalgae in sandy compared to muddy sandy surface sediments, chl $a$ and ATP based biomass seemed to be inversely related to mud content (Fig. 8c,d). Photoautotrophic biomass was directly related to ADOC and inversely related with bacterial biomass (Fig. 9a,b).

From a schematic, the relationships between microbial biomass, organic carbon, and sediment properties become especially obvious (Fig. 10). In surface horizons of sandy sediments, a high percentage of the total microbial biomass was made up of photoautotrophic, active biomass. The high photoautotrophic biomass coincided with high concentrations of ADOC, suggesting that the ADOC pool is mainly supplied by exuda-
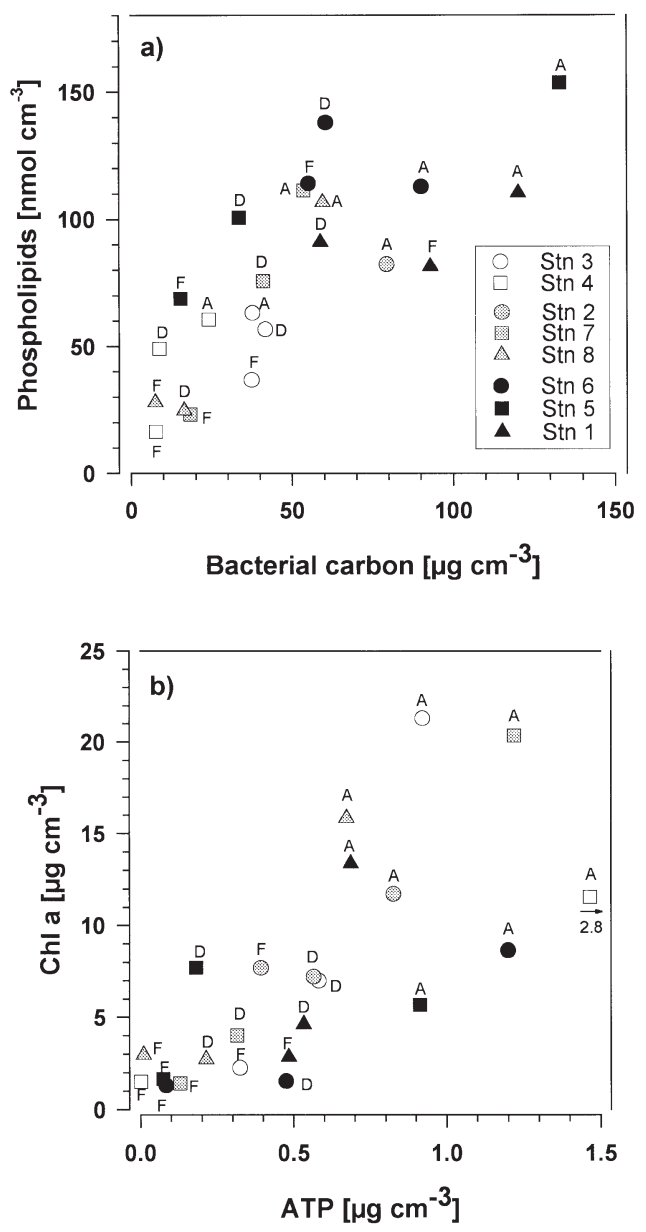

Fig. 7. Relationships between total phospholipid based microbial and bacterial biomass based on cell counts (a) and between chl $a$ and ATP (b) in sediments of the 8 stations sampled in the Rassower Strom. See Fig. 6 for letter-code explanation. Correlation equations for the relationships between phospholipid based microbial and bacterial biomass $(y=0.8 x$ $+35.7, \mathrm{r}=0.774, \mathrm{p}<0.001, \mathrm{n}=24)$ and between chl $a$ and ATP $(y=5.6 x+3.9, \mathrm{r}=0.561, \mathrm{p}<0.01, \mathrm{n}=23)$ were obtained

tion products from microphytobenthos. The high contribution of ADOC to TOC and DOC, the low C:N and $\mathrm{N}: \mathrm{P}$ ratios as well the high ratios of chl a to phaeopigments reflected the easily decomposable nature of the organic material, which seemed to be rapidly turned over, thus allowing no accumulation and aging. The important role of ADOC as a link between photoautotrophic and heterotrophic processes becomes obvious. With increasing mud content, total microbial and bacterial biomass increased, whereas photoautotrophic and active biomass decreased. This was accompanied by an increase in TOC and DOC and a decrease in ADOC. The accumulation of organic matter may arise from sedimentation or lateral transport from shallower areas. In muddy sand sediments low photoautotrophic biomass was consistent with low 

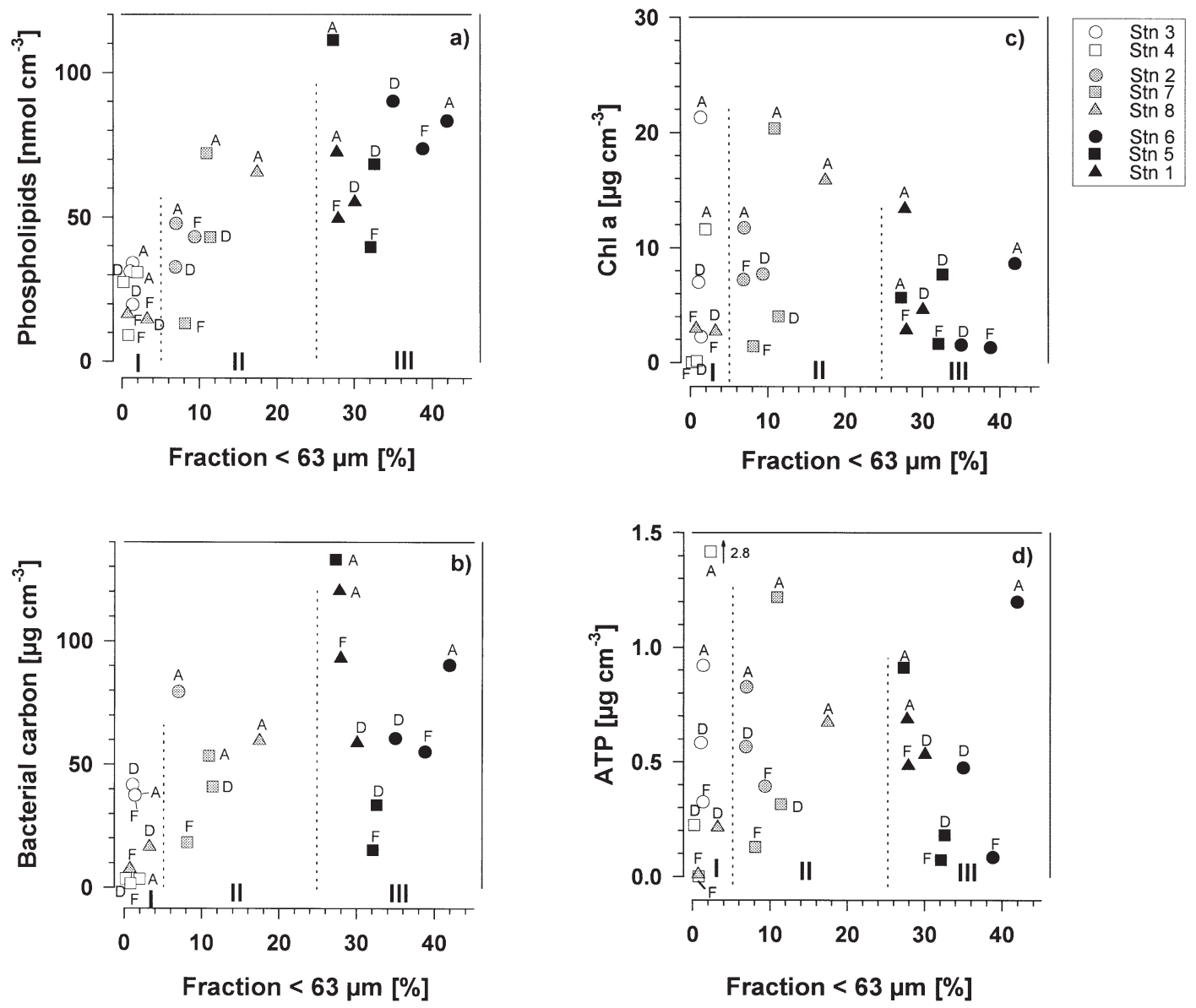

Fraction $<63 \mu \mathrm{m}[\%]$

Fig. 8. Relationships between mud content (expressed as percentage of the fraction $<63 \mu \mathrm{m}$ to total sediment dry weight) and different microbial biomass parameters (phospholipids, ATP, chl $a$ and bacterial biomass) in sediments of the 8 stations sampled in the Rassower Strom. See Fig. 6 for letter-code explanation. Correlations between mud content, phospholipid based and bacterial biomass were significant (correlations between mud content and phospholipid based biomass, $y=1.5 x+24.8, \mathrm{r}=0.777, \mathrm{p}<0.001$, $\mathrm{n}=24$, and between mud content and bacterial biomass, $y=1.4 x+24.7, \mathrm{r}=0.576, \mathrm{p}<0.01, \mathrm{n}=22$ ). Between mud content, chl $a$ and ATP based biomass significant linear correlations did not exist
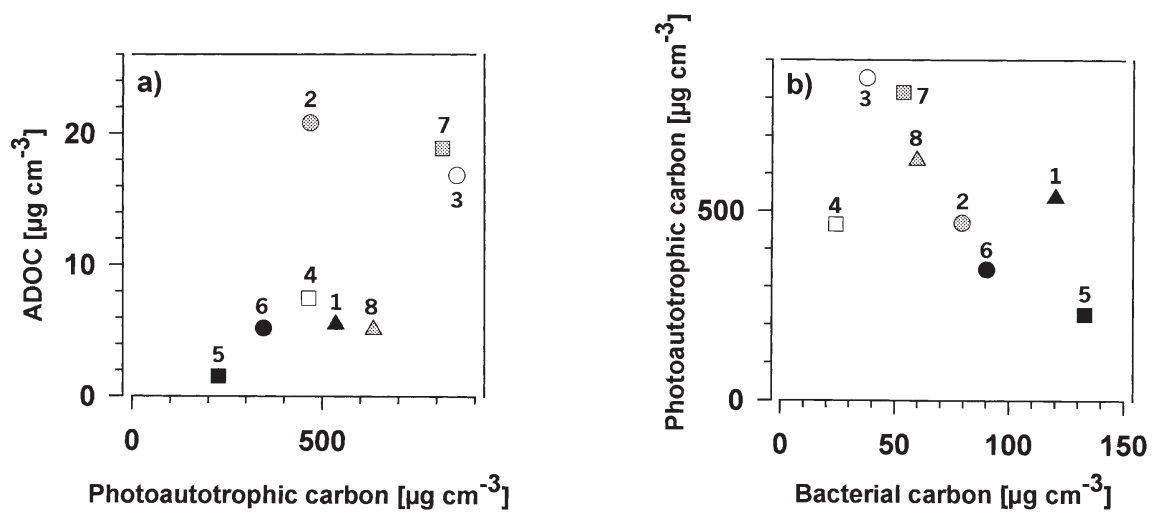

Fig. 9. Relationships between available dissolved organic carbon (ADOC) and photoautotrophic carbon (a) and between photoautotrophic and bacterial carbon (b) in surface sediments $(0-1 \mathrm{~cm})$ of the 8 stations sampled in the Rassower Strom. Numbers refer to the stations (Stns 3 and 4: sand; Stns 2,7 and 8: slightly muddy sand; Stns 1, 5 and 6: muddy sand). Correlation equations for the relationships between ADOC and photoautotrophic carbon $(y=0.02 x-5.1, \mathrm{r}=0.881, \mathrm{p}<0.01$, $\mathrm{n}=7$; data of Stn 2 were not considered for correlation equation) and between photoautotrophic and bacterial carbon $(y=-3.6 x+808.8, r=0.631, p<0.05$, $\mathrm{n}=8$ ) were obtained 
Sand
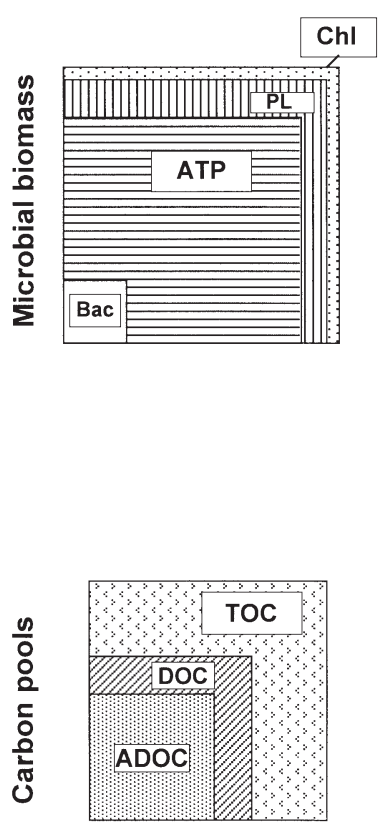

Slightly muddy sand
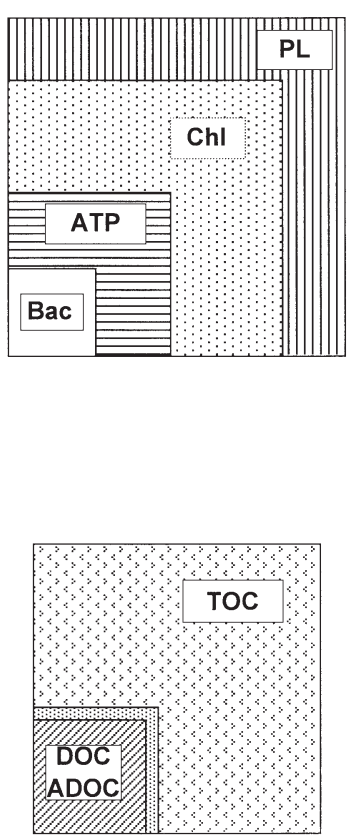

Muddy sand
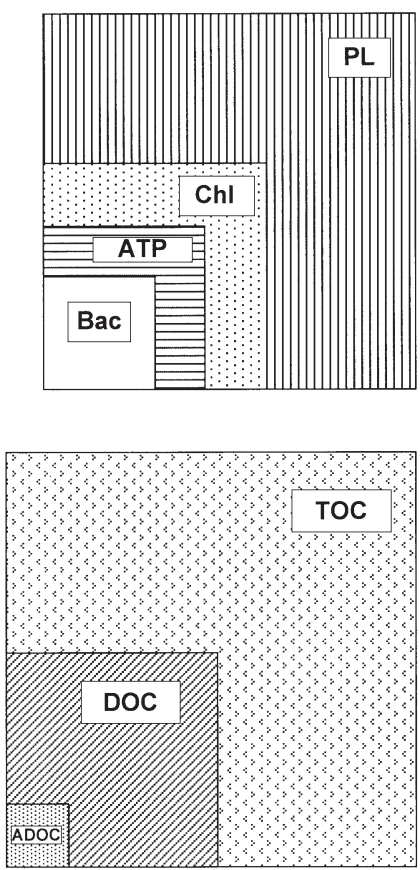

Increases in enzymatic decomposition of organic matter, C:N-, and N:P-ratios

Increase in mud content

Fig. 10. Schematic illustrating the relations between the pools of organic carbon and microbial biomass, and sediment properties in sediments of the Rassower Strom. Microbial biomass and organic carbon were derived from mean values calculated for surface horizons $(0-1 \mathrm{~cm})$ of each sediment group (PL = phospholipid based biomass; ATP = ATP based biomass; Chl = chl $a$ based biomass; $\mathrm{Bac}=$ bacterial number based biomass; $\mathrm{TOC}=$ total organic carbon, $\mathrm{DOC}=$ dissolved organic carbon; $\mathrm{ADOC}=$ available dissolved organic carbon). The proportion between the different pools of microbial biomass and organic carbon are to scale. For appropriate illustration, TOC pools were reduced by a factor of 8

ADOC concentrations. The increase in $\mathrm{C}: \mathrm{N}$ and $\mathrm{N}: \mathrm{P}$ ratios as well as the decrease in the ratios between $\mathrm{chl}$ $a$ and phaeopigments pointed to the more resistant nature of the organic material. In these fine-grained sediments, bacteria gain increasing importance for the turnover of organic carbon. Through the enhanced enzymatic hydrolysis rates of high molecular weight material, low molecular weight compounds are provided for microbial respiration and growth.

\section{CONCLUSIONS}

Investigations of shallow water coastal sediments of the southern Baltic Sea (Rassower Strom, Nordrügensche Bodden) have allowed initial insight into functional relationships between sediment properties, organic matter, and microbial biomass. The differentiation of microbial biomass is limited by the low specificity of biomass indicators (phospholipids, ATP, chl a) to distinguish between different functional groups of organisms and the uncertainty of conversion factors to extrapolate biomass values based on carbon. Further information may be expected from the application of fluorescently labelled dyes or molecular techniques to follow shifts in the activities of different physiological groups of microorganisms. However, these techniques are difficult to apply to sediments.

Available dissolved organic carbon was identified as an important link between photoautotrophic and heterotrophic organisms. This fraction has to be supplied from photoautotrophic organisms or bacterial hydrolysis of higher molecular weight material in order to meet the energy and carbon demand of the bacteria. Further measurements are needed to follow relationships between primary production, release of ADOC and the activities of different physiological groups of microorganisms in sediments of different properties. For this purpose short-term measurements of oxygen, light, and ADOC with a combined set of microsensors are desirable. As well as concentration measurements of ADOC, its chemical nature 
should be analysed, which might be different in sediments with different origins of available organic carbon. A better knowledge of the interactions between sediment properties, organic matter and microbial biomass is required to understand the effects of eutrophication in coastal areas. Future investigations should include comparable sediments from areas of different eutrophication. As well as organic matter and microbial biomass pools, concentrations and fluxes of inorganic and organic nutrients should be measured.

Acknowledgements. The authors are grateful for the fieldwork assistance provided by Prof. Dr B. W. Flemming, Senckenberg Institut, Wilhelmshaven. The authors wish to thank Tina Brüggmann, Sandra Kläber, and Ingrid Kreuzer for their valuable assistance in the laboratory. We are grateful to the crews of the RVs 'Prof. F. Gessner' and 'Senckenberg' for doing the sampling. We also thank 4 anonymous reviewers for their helpful comments.

\section{LITERATURE CITED}

Amon RMW, Benner R (1994) Rapid cycling of high-molecular-weight dissolved organic matter in the ocean. Nature 369:549-552

Amon RMW, Benner R (1996) Bacterial utilization of different size classes of dissolved organic matter. Limnol Oceanogr 41:41-51

Andersen JM (1976) An ignition method for the determination of total phosphorus in lake sediments. Water Res 10: 329-331

Andersson A, Rudehäll A (1993) Proportion of plankton biomass in particulate organic carbon in the northern Baltic Sea. Mar Ecol Prog Ser 95:133-139

Atlas RM, Bartha R (1987) Microbial ecology: fundamentals and application. The Benjamin/Cummings Publishing Comp, Inc, Menlo Park, CA

Balkwill DL, Leach FR, Wilson JT, McNabb JF, White DC (1988) Equivalence of microbial biomass measures based on membrane lipid and cell wall components, adenosine triphosphate, and direct counts in subsurface aquifer sediments. Microb Ecol 16:73-84

Balzer W, Erlenkeuser H, Hartmann M, Müller PJ, Pollehne F (1987) Diagenesis and exchange processes at the benthic boundary. In: Rumohr J, Walger E, Zeitzschel B (eds) Seawater-sediment interactions in coastal waters-an interdisciplinary approach. Lecture Notes on Coastal and Estuarine Studies 13. Springer-Verlag, Berlin, p 111-161

Barlow RG, Mantoura RFC, Peinert RD, Miller AEJ, Fileman TW (1995) Distribution, sedimentation and fate of biomarkers following thermal stratification in the western Alboran Sea. Mar Ecol Prog Ser 125:279-291

Barnett PRO, Watson J, Conelly D (1984) A multiple corer for taking virtually undisturbed samples from shelf, bathyal and abyssal sediments. Oceanol Acta 7:339-409

Bird DF, Duarte CM (1989) Bacteria-organic matter relationship in sediments: a case of spurious correlation. Can J Fish Aquat Sci 46:904-908

Black HJ, Köster M, Meyer-Reil LA, Andres D (1995) Dokumentation von Benthosgemeinschaften in Flachwasserbe- reichen der Nordrügenschen Boddengewässer. Abschlußbericht, Deutsche Bundesstiftung Umwelt, Osnabrück

Borch NH, Kirchman DL (1999) Protection of protein from bacterial degradation by submicron particles. Aquat Microb Ecol 16:265-272

Boschker HTS, de Brouwer JFC, Cappenberg TE (1999) The contribution of macrophyte-derived organic matter to microbial biomass in salt-marsh sediments: stable carbon isotope analysis of microbial biomarkers. Limnol Oceanogr 44:309-319

Bott TL, Kaplan KA (1985) Bacterial biomass, metabolic state, and activity in stream sediments: relation to environmental variables and multiple assay comparisons. Appl Environ Microbiol 50:508-522

Bratbak G, Jacobsen A, Heldal M (1998) Viral lysis of Phaeocystis pouchetii and bacterial secondary production. Aquat Microb Ecol 16:11-16

Cammen LM (1991) Annual bacterial production in relation to benthic microalgal production and sediment oxygen uptake in an intertidal sandflat and an intertidal mudflat. Mar Ecol Prog Ser 71:13-25

Cariou-Le Gall V, Blanchard GF (1995) Monthly HPLC measurements of pigment concentration from an intertidal muddy sediment of Marennes-Oléron Bay, France. Mar Ecol Prog Ser 121:171-179

Cauwet G (1999) Determination of dissolved organic carbon and nitrogen by high temperature combustion. In: Grasshoff K, Kremling K, Ehrhardt M (eds) Methods of seawater analysis, Wiley-VCH, Weinheim, p 407-420

Dale NG (1974) Bacteria in intertidal sediments: factors related to their distribution. Limnol Oceanogr 19:509-518

de Flaun MF, Mayer LM (1983) Relationships between bacteria and grain surfaces in intertidal sediments. Limnol Oceanogr 28:873-881

de Jonge VN, Colijn F (1994) Dynamics of microphytobenthos biomass in the Ems estuary. Mar Ecol Prog Ser 104: 185-196

Delafontaine MT, Bartholomä A, Flemming BW, Kurmis R (1996) Volume-specific dry POC mass in surficial intertidal sediments: a comparison between biogenic muds and adjacent sand flats. Senckenberg Marit 26:167-178

Deming JW, Baross JA (1993) The early diagenesis of organic matter: bacterial activity. In: Engel MH, Macko SA (eds) Organic geochemistry. Plenum Press, New York, p 119-144

Ducklow HW, Carlson CA (1992) Oceanic bacterial production. Adv Microb Ecol 12:113-181

Fabiano M, Danovaro R (1998) Enzymatic activity, bacterial distribution, and organic matter composition in sediments of the Ross Sea (Antarctica). Appl Environ Microb 64: $3838-3845$

Figge K, Köster R, Thiel H, Wieland P (1980) Schlickuntersuchungen im Wattenmeer der Deutschen Bucht. Zwischenbericht über ein Forschungsprojekt des KFKI. Die Küste 35:187-204

Findlay RH, King GM, Watling L (1989) Efficacy of phospholipid analysis in determining microbial biomass in sediments. Appl Environ Microbiol 55:2888-2893

Fry JC (1988) Determination of biomass. In: Austin B (ed) Methods in aquatic bacteriology. John Wiley and Sons, Chichester, p 27-72

Grasshoff K, Kremling K, Ehrhardt M (1999) Methods of seawater analysis, Wiley-VCH, Weinheim

Hansen JW, Lomstein BAa (1999) Leakage of ammonium, urea, and dissolved organic nitrogen and carbon from eelgrass Zostera marina roots and rhizomes during sediment handling. Mar Ecol Prog Ser 16:303-307

Hargrave BT (1972) Aerobic decomposition of sediment and 
detritus as a function of particle surface area and organic content. Limnol Oceanogr 17:583-596

HELCOM (Helsinki Commission) (1988) Guidelines for the Baltic Monitoring Programme for the third stage. Loose sheet version of the Baltic Sea Environment Proceedings No. 27D. Helsinki Commission, Helsinki, p 1-60

Herbert RA (1990) Methods for enumerating microorganisms and determining biomass in natural environments. In: Grigorova R, Norris JR (eds) Methods in microbiology, Vol 22. Academic Press, Cambridge, p 1-39

Holmer M (1996) Composition and fate of dissolved organic carbon derived from phytoplankton detritus in coastal marine sediments. Mar Ecol Prog Ser 141:217-228

Ingall ED, van Cappelen P (1990) Relation between sedimentation rate and burial of organic phosphorus and organic carbon in marine sediments. Geochim Cosmochim Acta 54:373-386

Jeffrey SW, Hallegraeff GM (1980) Studies of phytoplankton species and photosynthetic pigments in a warm core eddy of the east Australian current. II. A note on pigment methodology. Mar Ecol Prog Ser 3:295-301

Karl DM (1980) Cellular nucleotide measurements and applications in microbial ecology. Microb Rev 44:739-796

Karl DM $(1986)$ Determination of in situ microbial biomass, viability, metabolism, and growth. In: Pointdexter JS, Leadbetter ER (eds) Bacteria in nature, Vol 2: Methods and special applications in microbial ecology. Plenum Press, New York, p 85-176

Karl DM (1993) Total microbial biomass estimation derived from the measurement of particulate adenosine-5'triphosphate. In: Kemp PF, Sherr BF, Sherr EB, Cole JJ (eds) Handbook of methods in aquatic microbial ecology. Lewis Publishers, Boca Raton, FL, p 359-368

Keil RG, Montlucon DB, Prahl FG, Hedges JI (1994) Sorptive preservation of labile organic matter in marine sediments. Nature 370:639-641

Köster M, Dahlke, S, Meyer-Reil LA (1997) Microbiological studies along a gradient of eutrophication in a shallow coastal inlet in the southern Baltic Sea (Nordrügensche Bodden). Mar Ecol Prog Ser 152:27-39

Laws EA, Karl DM, Redalje DG, Jurick RS, Winn CD (1983) Variability in ratios of phytoplankton carbon and RNA to ATP and chl $a$ in batch and continuous cultures. J Phycol 19:439-445

Lucas CH, Holligan PM (1999) Nature and ecological implications of algal pigment diversity on the Molenplaat tidal flat (Westerschelde estuary, SW Netherlands). Mar Ecol Prog Ser 180:51-64

Mari X (1999) Carbon content and C:N ratio of transparent exopolymeric particles (TEP) produced by bubbling exudates of diatoms. Mar Ecol Prog Ser 183:59-71

Mayer LM (1994) Relationships between mineral surfaces and organic carbon concentrations in soils and sediments. Chem Geol 114:347-363

McCarthy MD, Hedges JI, Benner R (1993) The chemical composition of dissolved organic matter in seawater. Chem Geol 107:503-507

Meyer-Reil LA (1983) Benthic response to sedimentation events during autumn to spring at a shallow water station in the Western Kiel Bight. II. Analysis of benthic bacterial populations. Mar Biol 77:247-256

Meyer-Reil LA (1986) Spatial and temporal distribution of bacterial populations in marine shallow water surface sediments. In: Lasserre P, Martin JM (eds) Biogeochemical processes at the land-sea boundary. Elsevier Oceanography Series, Vol 43. Elsevier, Amsterdam, p141-160
Meyer-Reil LA (1993) Mikrobielle Besiedlung und Produktion. In: Meyer-Reil LA, Köster M (eds) Mikrobiologie des Meeresbodens. Gustav Fischer Verlag, Jena, p 38-81

Meyer-Reil LA (1994) Microbial life in sedimentary biofilms the challenge to microbial ecologists. Mar Ecol Prog Ser 112:303-311

Middelburg JJ, Klaver G, Nieuwenhuize J, Wielemaker A, de Haas W, Vlug T, van der Nat JFWA (1996) Organic matter mineralization in intertidal sediments along an estuarine gradient. Mar Ecol Prog Ser 132:157-168

Moriarty DJW, Iverson RL, Pollard PC (1986) Exudation of organic carbon by the seagrass Halodule wrightii Aschers. and its effect on bacterial growth in the sediment. J Exp Mar Biol Ecol 96:115-126

Nedwell DB (1987) Distribution and pool sizes of microbially available carbon in sediment measured by a microbiological assay. FEMS Microbiol Ecol 45:47-52

Neudörfer F, Meyer-Reil LA (1997) A microbial biosensor for the microscale measurement of bioavailable organic carbon in oxic sediments. Mar Ecol Prog Ser 147:295-300

Orem WH, Gaudette HE (1984) Organic matter in anoxic marine pore water: oxidation effects. Org Geochem 5: 175-181

Paerl HW, Tilzer MM, Goldman CR (1976) Chlorophyll a versus adenosine triphosphate as algal biomass indicators in lakes. J Phycol 12:242-246

Parkes RJ (1987) Analysis of microbial communities within sediments using biomarkers. In: Fletcher M, Gray TRG, Jones JG (eds) Ecology of microbial communities. Cambridge University Press, Cambridge, p 147-177

Pelegri SP, Dolan J, Rassoulzadegan F (1999) Use of high temperature catalytic oxidation (HTCO) to measure carbon content of microorganisms. Aquat Microb Ecol 16: 273-280

Raimbault P, Diaz F, Pouvesle W, Boudjellal B (1999) Simultanous determination of particulate organic carbon, nitrogen and phosphorus collected on filters, using a semiautomatic wet-oxidation method. Mar Ecol Prog Ser 180: 289-295

Rieling T (1999) Remineralisation organischen Materials in Boddengewässern Mecklenburg-Vorpommerns unter besonderer Berücksichtigung der Bedeutung von Partikeln und Aggregaten. PhD thesis, University of Greifswald

Rublee PA (1982) Bacteria and microbial distribution in estuarine sediments. In: Kennedy VS (ed) Estuarine comparisons. Academic Press, New York, p 159-181

Sañudo-Wilhelmy SA, Taylor GT (1999) Bacterioplankton dynamics and organic carbon partitioning in the lower Hudson River estuary. Mar Ecol Prog Ser 182:17-27

Sun MY, Lee C, Aller RC (1993) Laboratory studies of oxic and anoxic degradation of chlorophyll-a in Long Island Sound sediments. Geochim Cosmochim Acta 57:147-157

Tupas LM, Popp BN, Karl DM (1994) Dissolved organic carbon in oligotrophic waters: experiments on sample preservation, storage and analysis. Mar Chem 45:207-216

Volk CJ, Volk CB, Kaplan LA (1997) Chemical composition of biodegradable dissolved organic matter in streamwater. Limnol Oceanogr 42:39-44

White DC, Pinkart HC, Ringelberg DB (1997) Biomass measurements: biochemical approaches. In: Hurst CJ, Knudsen GR, McInerney MJ, Stetzenbach LD, Walter MV (eds) Manual of environmental microbiology. ASM Press, Washington, DC, p 91-101

Ziegler S, Benner R (1999) Dissolved organic carbon cycling in a subtropical seagrass-dominated lagoon. Mar Ecol Prog Ser 180:149-160

Submitted: August 31, 2000; Accepted: November 28, 2000 Proofs received from author(s): March 7, 2001 